\title{
Pancreatic Cancer and Cellular Senescence: Tumor Microenvironment under the Spotlight
}

\author{
Michela Cortesi ${ }^{1, *(D)}$, Michele Zanoni ${ }^{1}$, Francesca Pirini ${ }^{1}\left(\mathbb{D}\right.$, Maria Maddalena Tumedei ${ }^{1}$, Sara Ravaioli $^{1}$ (D), \\ Ilario Giovanni Rapposelli ${ }^{2}$, Giovanni Luca Frassineti ${ }^{2}$ and Sara Bravaccini ${ }^{1}$ (D) \\ 1 Biosciences Laboratory, IRCCS Istituto Romagnolo per lo Studio dei Tumori (IRST) "Dino Amadori", \\ 47014 Meldola, Italy; michele.zanoni@irst.emr.it (M.Z.); francesca.pirini@irst.emr.it (F.P.); \\ maria.tumedei@irst.emr.it (M.M.T.); sara.ravaioli@irst.emr.it (S.R.); sara.bravaccini@irst.emr.it (S.B.) \\ 2 Department of Medical Oncology, IRCCS Istituto Romagnolo per lo Studio dei Tumori (IRST) "Dino \\ Amadori”, 47014 Meldola, Italy; ilario.rapposelli@irst.emr.it (I.G.R.); luca.frassineti@irst.emr.it (G.L.F.) \\ * Correspondence: michela.cortesi@irst.emr.it
}

\section{check for}

Citation: Cortesi, M.; Zanoni, M.;

Pirini, F.; Tumedei, M.M.; Ravaioli, S.; Rapposelli, I.G.; Frassineti, G.L.; Bravaccini, S. Pancreatic Cancer and Cellular Senescence: Tumor Microenvironment under the Spotlight. Int. J. Mol. Sci. 2022, 23, 254. https://doi.org/10.3390/ ijms23010254

Academic Editor:

Atsushi Matsuzawa

Received: 23 November 2021

Accepted: 24 December 2021

Published: 27 December 2021

Publisher's Note: MDPI stays neutral with regard to jurisdictional claims in published maps and institutional affiliations.

Copyright: (C) 2021 by the authors. Licensee MDPI, Basel, Switzerland. This article is an open access article distributed under the terms and conditions of the Creative Commons Attribution (CC BY) license (https:// creativecommons.org/licenses/by/ $4.0 /$ )

\begin{abstract}
Pancreatic ductal adenocarcinoma (PDAC) has one of the most dismal prognoses of all cancers due to its late manifestation and resistance to current therapies. Accumulating evidence has suggested that the malignant behavior of this cancer is mainly influenced by the associated strongly immunosuppressive, desmoplastic microenvironment and by the relatively low mutational burden. PDAC develops and progresses through a multi-step process. Early in tumorigenesis, cancer cells must evade the effects of cellular senescence, which slows proliferation and promotes the immune-mediated elimination of pre-malignant cells. The role of senescence as a tumor suppressor has been well-established; however, recent evidence has revealed novel pro-tumorigenic paracrine functions of senescent cells towards their microenvironment. Understanding the interactions between tumors and their microenvironment is a growing research field, with evidence having been provided that non-tumoral cells composing the tumor microenvironment (TME) influence tumor proliferation, metabolism, cell death, and therapeutic resistance. Simultaneously, cancer cells shape a tumor-supportive and immunosuppressive environment, influencing both non-tumoral neighboring and distant cells. The overall intention of this review is to provide an overview of the interplay that occurs between senescent and non-senescent cell types and to describe how such interplay may have an impact on PDAC progression. Specifically, the effects and the molecular changes occurring in non-cancerous cells during senescence, and how these may contribute to a tumor-permissive microenvironment, will be discussed. Finally, senescence targeting strategies will be briefly introduced, highlighting their potential in the treatment of PDAC.
\end{abstract}

Keywords: senescence; pancreatic cancer; tumor microenvironment; SASP; senotherapeutics

\section{Introduction}

Despite therapeutic advances and the improvement of medical technologies, pancreatic cancer remains a highly lethal cancer, representing the fourth leading cause of cancer death in both men and women [1]. Only approximately $20 \%$ of patients diagnosed with pancreatic ductal adenocarcinoma (PDAC) are eligible for treatment with curative intent (i.e., surgical resection in combination with adjuvant and/or pre-operative therapy) [2]. However, despite the complete resection of the tumor, the majority of patients will recur locally or at distant sites and die within 5 years [3]. PDAC's negative prognosis is mainly ascribable to its late diagnosis, and great efforts have been made in recent years for the identification of early diagnosis biomarkers [4]. As compared to other solid tumors, PDAC shows great genetic intra- and inter-tumoral heterogeneity, contributing to a lack of clinical and molecular classification systems which are able to improve patient management [5]. Moreover, the abundant presence of dense stroma, together with tissue inflammation, makes this tumor unique [6]. The stroma surrounding PDAC may represent 
up to $90 \%$ of the whole tumor and is characterized by a low oxygen concentration, poor vascularization, and extensive fibrosis associated with variable immune infiltrate [7]. The fibrotic portion of the tumor consists of both cellular and non-cellular components, the former being mainly composed of cancer-associated fibroblasts (CAFs), endothelial cells, and pancreatic stellate cells (PSCs) while the latter is composed of different extracellular matrix (ECM) molecules, such as collagen, glycosaminoglycans, proteoglycans, and growth factors, further enhancing tumor heterogeneity [8].

Senescence is a well-known tumor suppressor mechanism; however, paracrine signaling of senescent cells has recently gained attention for its pro-tumorigenic effect. Different stimuli are known to trigger cellular senescence, in particular those inducing genotoxic, oncogenic, oxidative, and replicative stress $[9,10]$. Regardless of the stimuli, senescent cells share some common behaviors, among which the main ones are growth arrest, apoptosis resistance, sustained DNA damage signaling, and heterochromatin modifications [11]. Despite an inability to proliferate, these cells still remain metabolically active and secrete a plethora of molecules-termed, as a whole, as senescent-associated secretory phenotype (SASP) - fostering cellular senescence through both autocrine and paracrine signaling [12-14]. Importantly, the SASP is considered the main driver of senescence-related pro-tumorigenic effects, as it can be involved in cancer relapse and metastases, transforming the neighboring cells (both tumor and non-tumor), and destructing the ECM [15-17].

In this review, the hallmarks and the mechanisms of senescence induction will be summarized, and the role of senescence in PDAC progression with respect to the heterogeneity of the tumor will be addressed. Specifically, the senescence-related cellular and molecular changes occurring in the TME and how they may contribute to a tumor-permissive microenvironment will be discussed. Finally, future therapeutic options targeting senescent cells will be briefly introduced and their potential discussed in the treatment of PDAC.

\section{Pancreatic Ductal Adenocarcinoma Heterogeneity}

\subsection{Genetic Heterogeneity}

PDAC is the most common type of pancreatic cancer, arising from the exocrine compartment of the pancreas. The actual progression model of PDAC describes the transformation of acinar cells into ductal-like cells as the initial step of tumorigenesis as a consequence of a stressful event (i.e., tissue damage, inflammation). This transformation makes the cells more susceptible to pro-oncogenic events, thus promoting the onset of intra-epithelial neoplasias (PanINs), followed by sequential tumor suppressor gene mutations, leading to cancer progression [18]. It has been well-established that four main mutational events progressively accumulate in PDAC, driving the tumorigenesis: Kirsten rat sarcoma viral oncogene homolog (KRAS) activation, followed by cyclin-dependent kinase inhibitor $2 \mathrm{~A}$ (CDKN2A), tumor protein p53 gene (TP53), and SMAD family member 4 (SMAD4) inactivation $[5,19,20]$. KRAS mutations show the highest frequency in PDAC, with more than $90 \%$ of tumors harboring oncogenic point mutations of this gene. These mutations are considered a marker of poor prognosis and lead to a wide range of functional consequences [21]. Inactivating mutations of TP53 have been reported in more than 50\% of pancreatic cancers and commonly cause apoptosis evasion, cell cycle progression, and disabling DNA damage repair [22]. Mutations in CDKN2A ( $>40 \%)$ are mainly related to cell cycle dysregulation, promoting cell cycle progression through the loss of cyclin-dependent kinase (CDK) 4 and CDK6 inhibition. Finally, more than $30 \%$ of PDAC have been reported to show SMAD4 mutations, which occur at the latest stages of tumorigenesis and promote cell survival through non-canonical TGF-beta signaling [23] (Figure 1A). In addition to these common alterations, a wide number of less-frequent mutations may occur (e.g., mutations in DNA damage repair genes [24], mismatch repair genes [25], PI3K/AKT/mTOR signaling pathways genes [26], and so on), resulting in genetic heterogeneity of PDAC [27]. Notably, such heterogeneity is not only due to genetic cues, but also due to epigenetic mechanisms which are capable of regulating both tumor suppressors and oncogenes [28]. Epigenetic regulatory genes, such as those encoding for chromatin remodeling complexes, histone methylases, 
histone methyltransferase, and histone demethylases, are indeed frequently mutated in PDAC [24,29]. The heterogeneous genetic nature of PDAC highlights the necessity of personalized treatment strategies based on patient stratification; however, a consensus classification is still lacking.

A

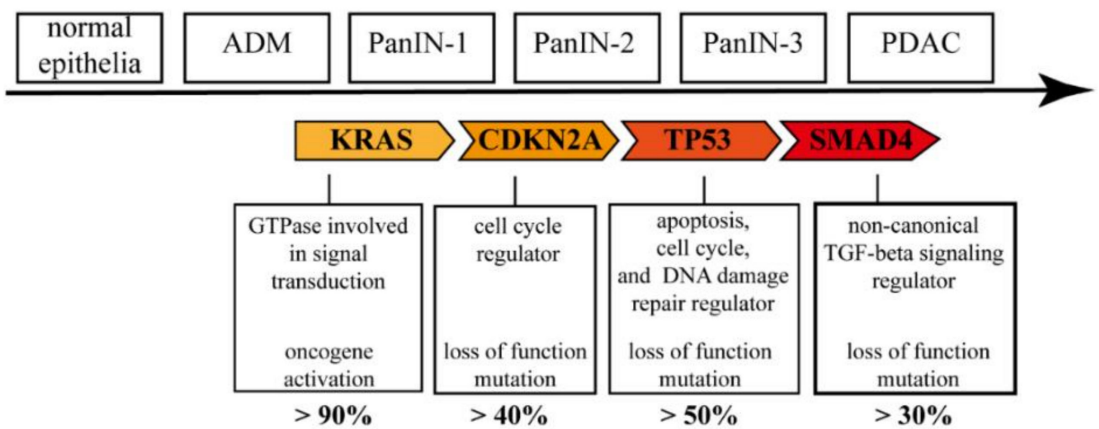

Desmoplasia

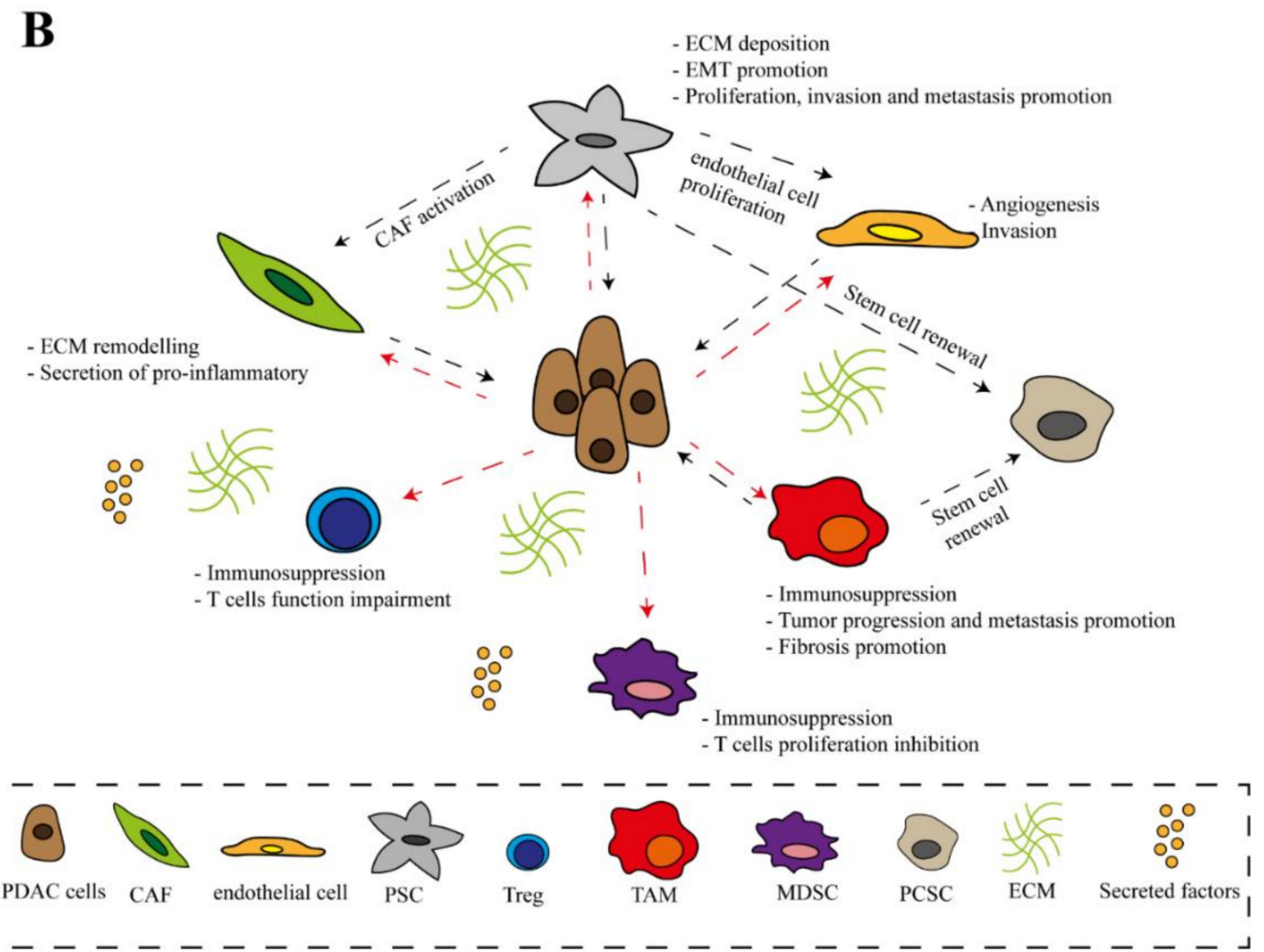

Figure 1. Pancreatic cancer heterogeneity. (A) The progression model of PDAC is driven by KRAS, TP53, CDKN2A, and SMAD4 mutations, which modulate tumor initiation and progression; (B) crosstalk between tumor cells and non-tumor cells in PDAC microenvironment. Abbreviations: PDAC, pancreatic ductal adenocarcinoma; CAF, cancer-associated fibroblast; PSC, pancreatic stellate cell; Treg, regulatory T cell; TAM, tumor-associated macrophage; MDSC, myeloid-derived suppressor cell; PCSC, pancreatic cancer stem cell; ECM, extracellular matrix. 


\subsection{Tumor Microenvironment}

Pancreatic cancer resides in an extensive and complex fibrous stroma consisting of a small, but heterogeneous, cellular fraction and a non-cellular fraction [30]. The so-called desmoplastic reaction of the tumor is a hallmark of PDAC, which is present in both primary and metastatic lesions and which makes this tumor unique when compared to other solid tumors [31]. The stromal reaction arises from pancreatic stellate cells (PSCs) that, once activated by tumor cells, start to deposit the fibrotic matrix [32]. In addition to PSCs, fibroblasts, immune cells, endothelial cells, and pancreatic cancer stem cells have been mainly identified in the TME [33] (Figure 1B). The cellular and non-cellular components of the TME maintain tissue homeostasis. The complex interplay between the TME and tumor cells can alternatively promote or suppress cancer development and progression based on context-dependent stromal alterations [34].

\subsubsection{Pancreatic Stellate Cells (PSCs)}

PSCs are star-shaped quiescent stromal cells that, in their inactive state, serve as storage for vitamin A droplets, in addition to being involved in normal pancreas secretions, immunity, and in the maintenance of stroma homeostasis [35]. PSCs become activated once exposed to environmental factors-namely, oxygen variations and reactive oxygen species (ROS) generation - or to secretory molecules, such as cytokines, growth factors, and other signaling molecules [36]. Activated PSCs acquire proliferative and migratory capabilities, while showing an increased production of cytokines (e.g., IL-1, -6, -8, and -10) and growth factors (e.g., insulin-like growth factor 1 (IGF1); vascular endothelial growth factor (VEGF); platelet-derived growth factor (PDGF); fibroblast growth factor (FGF); and CXC motif chemokine 12 (CXCL12)) [37]. The production of signaling molecules sustains, through an autocrine loop, the activation of PSCs themselves and promotes the angiogenesis, proliferation, migration, and invasion of cancer cells through paracrine signaling [38]. However, the activation of these cells is not permanent, as PSCs can regress to a quiescent state under the influence of several processes, such as senescence or tissue recovery $[38,39]$. Interestingly, recent studies have shown that PSCs and cancer cells establish reciprocal interactions, which significantly contribute to PDAC growth and aggressiveness [40,41]. It has been reported that, the secretion of cytokines, such as IL-6, by PSCs seems to be involved in promoting the immunosuppressive properties of the TME and in supporting the invasiveness of PDAC [42]. The main marker of PSC activation is the expression of alpha-smooth muscle actin ( $\alpha$-SMA) together with the deposition of a high amount of extracellular matrix (ECM) [36]. The deposition of ECM molecules, such as collagens, hyaluronic acid, laminin, tenascin- $\mathrm{C}$, and fibronectin, modulate the viability, adhesion, and migration properties of tumor cells [43]. This matrix also acts as a physical barrier, contributing to the intra-tumoral hypoxia, compressing blood vessels, and impairing drug delivery to PDAC cells [44]. Activated PSCs have been shown to be able to remodel the ECM in PDAC, promoting an increase in tissue stiffening and in the crosslinking of collagen fibers [45]. Moreover, they can also promote the epithelial-mesenchymal transition (EMT) of tumor cells, which fosters tumor invasion and metastasization. Indeed, it has been demonstrated that cancer cells located at the invasive front of the tumor show a decreased expression of epithelial markers (e.g., e-cadherin) and an increased expression of mesenchymal markers (e.g., vimentin) as a consequence of exposure to stromal cell signals [46].

\subsubsection{Cancer-Associated Fibroblasts (CAFs)}

CAFs are one of the most represented and dynamic elements composing the PDAC stroma [47]. They may derive from different types of cells, including resident fibroblasts, bone marrow-derived mesenchymal stem cells, and epithelial cells; however, it is commonly believed that one of the main CAF sources in PDAC is activated PSCs $[36,48,49]$. CAFs and PDAC cells mutually promote each other's proliferation and differentiation [50]. Importantly, CAF activation is dependent on a plethora of complex mechanisms involving 
pro-inflammatory signals [51], changes in physical ECM properties [52,53], contact with cancer cells [54], or even physiological and genomic stresses [55]. As a consequence of their multiple origins and activation mechanisms, CAFs display different phenotypes and functions in PDAC, also representing an additional source of heterogeneity for this tumor. The function of CAFs as tumor promoters relies on their ability to boost tumor cell proliferation, invasion, and metastasis, as well as their pro-inflammatory and immunosuppressive properties [56]. Furthermore, CAFs have been shown to play a protective role towards cancer cells exposed to radiation or chemotherapy [57]. Despite their well-established role in supporting tumor progression, some studies have observed that CAF depletion results in higher proliferation and migration abilities of tumor cells, thus highlighting a possible role of CAFs as a barrier which is able to limit the spread of PDAC cells [58]. According to these findings, different subtypes of CAFs have been recently identified: myofibroblastic CAFs (myCAF), expressing $\alpha$-SMA and characterized by periglandular localization, and inflammatory CAFs (iCAF), expressing high levels of pro-inflammatory cytokines and chemokines [59].

\subsubsection{Immune Cells}

Pancreatic cancer is commonly depicted as an immunologically cold tumor; however, some studies have demonstrated a crucial role of immunological processes in PDAC tumorigenesis [60]. Importantly, inflammation has a tight connection with PDAC development and progression, and chronic pancreatitis is an established risk factor for the development of this cancer [61]. The TME of PDAC is basically immunosuppressive, including regulatory T cells (Treg), myeloid-derived suppressor cells (MDSCs), and tumor-associated macrophages (TAMs) [62].

Tregs (CD4+ and CD25+) are suppressor $\mathrm{T}$ cells with the function of preventing autoimmune diseases through the inhibition of effector T cells [63]. In PDAC, they are recruited by tumor cells into the TME, where they contribute to immunosuppression, thus supporting tumor progression; as such, they represent an unfavorable prognostic factor for patients [64]. Tregs exploit their immunosuppressive function through the modulation of several pathways. They can hinder CD8+ T cell activity through the secretion of cytokines and growth factors, such as IL-10 and TGF $\beta$, or by the expression of immune checkpoints (e.g., CTLA-4), leading to effector T cell dysfunction due to the up-regulation of the IDO pathway [65].

MDSCs are a heterogeneous population of cells of myeloid origin which expand during cancer, inflammation, and infection and which play a critical role in suppressing $\mathrm{T}$ cell responses [66]. In PDAC patients, a high presence of MDSCs in the peripheral blood may serve as a predictor of chemotherapy failure [67]. In pancreatic cancer, MDSCs are recruited by tumor cells to the TME, mainly as a consequence of granulocyte macrophage colony-stimulating factor (GM-CSF) production [68]. The up-regulation of GM-CSF may be induced by the KRAS ${ }^{\mathrm{G} 12 \mathrm{D}}$ mutation, which is detected in almost all cases of PDAC. Once in the TME, MDSCs suppress effector T cells, affecting several different pathways. For instance, they can induce oxidative stress in $\mathrm{T}$ cells through the production of ROS, resulting in the impairment of $\mathrm{T}$ cell protein translation and leading to a lack of antigendependent proliferation [69]. In addition, MDSCs can inhibit T cell proliferation through the depletion of L-arginine from the tumor microenvironment by a STAT3-dependent mechanism. Furthermore, MDSCs have shown an ability to prime and maintain the development of Tregs shaping the tumor stroma [70].

TAMs are M2-like macrophages endowed with immunosuppressive properties which foster tumor progression [71]. They are activated by the IL-4, IL-13, CSF-1, TGF- $\beta$, and IL-10 produced by cells in the TME. These secreted factors drive myeloid progenitor cell differentiation into monocytes and macrophages, favoring their recruitment within the microenvironment [72]. The immunosuppressive properties of TAMs are mainly related to the secretion of particular cytokines, chemokines, and enzymes [73]; to their ability to modulate T cell metabolism through the expression of Arg1 in a manner similar to that 
of MDSCs [74]; and to the ability of these cells to allow for Treg recruitment. Moreover, TAMs sustain PSCs in the deposition of ECM, thus contributing to pancreatic desmoplasia. In particular, TAMs drive PDAC fibrosis through the PI3K pathway and through the production of TGF- $\beta 1$ and PDGF, which stimulate PSC proliferation and ECM secretion, respectively $[75,76]$. Consistent with the immunosuppressive functions of TAM, it has been reported that the overall survival of PDAC patients with high M2-like macrophage density is lower when compared to patients with low M2-like macrophage density.

\subsubsection{Other Cell Populations}

Besides the cell populations mentioned above, endothelial cells and pancreatic cancer stem cells (PCSCs) deserve to be mentioned, even if they are less represented as compared to other cell types within the TME [77]. In PDAC, the low oxygen concentration and the need for nutrients lead to the induction of angiogenesis through the proliferation of endothelial cells from pre-existing vessels. This process, in pancreatic cancer, is regulated by the complex network of different cells composing the TME. For instance, in vitro studies have demonstrated that endothelial cell proliferation is regulated by secreted factors produced by both PSCs and tumor cells [78]. PSCs, upon oxygen restriction, have shown the ability to increase the production of collagen I and vascular endothelial growth factor (VEGF) with pro-angiogenic properties [79]. VEGF is also expressed in tumor cells, endothelial cells, and in TAMs and represents a marker of poor prognosis and high risk of recurrence in pancreatic cancer [80].

Finally, PCSCs are tumor cells that retain the ability to self-renew and to generate heterogeneous cell clones. PCSCs can promote the maintenance of their stemness features by autocrine signaling and influencing the shape of the TME [81]. Stromal cells, in turn, activate paracrine signaling that allows for the preservation of stem cells. In particular, PSCs and TAMs have been reported to promote the self-renewal and functional maintenance of PCSCs [82]. Overall, the main signaling pathways involved in supporting PCSC functions in PDAC are Hedgehog, Notch, and NF-KB, as well as PI3K/AKT and PTEN, all of which are highly de-regulated in this tumor [83].

\subsubsection{Non-Cellular Components of the Stroma}

The non-cellular portion of the PDAC stroma is mainly represented by a large amount of ECM, composed of fibrillar collagen, fibronectin, and laminin, as well as proteoglycans. ECM-composing molecules are mainly produced by CAFs and, to a lesser extent, PSCs and tumor cells, and they exploit the main function of the physical barrier [66]. Matrix components are able to form a complex network, binding to each other by means of adhesion receptors. A coherent signaling function of the ECM supporting cancer progression has been reported [84].

Collagens comprise $90 \%$ of the ECM in PDAC; type I and III are the most abundant, while type IV is less-represented. Notably, type I and III presence increases with the progression from pancreatic intraepithelial neoplasia to PDAC, whilst collagen type IV, together with laminin, divides endothelial cells from other components of the stroma [85]. Collagens shape the mechanical and physical properties of the TME, determining the stiffness of the matrix [86]. Within the TME, collagens are sensed by specific cellular receptors-integrins and discoidin domain receptors-that clusterize upon binding to collagen fibers, leading to the formation of focal adhesions which serve as a connection between the ECM and intracellular proteins. These connections activate multiple signaling pathways involved in the initiation of the EMT, allowing for cell migration [87]. Fibronectin, despite its ability to bind integrins, seems to not be related to EMT; however, it also binds collagens, suggesting an indirect contribution to the promotion of this mechanism [88].

In addition to collagens and fibronectin, hyaluronic acid is highly represented in the PDAC microenvironment. This glycosaminoglycan has the function of maintaining tissue hydration through its water-absorbent properties. However, if present in an excessive 
amount, it causes an imbalance of interstitial pressure, leading to vessel collapse and hence hampering drug delivery [89].

\section{Cellular Senescence: An Overview}

\subsection{Cellular Senescence}

Senescence was first described as the cessation of cell proliferation of diploid cells caused by telomere shortening [90]. To date, different mechanisms of senescence have been described in several cell types, including fibroblasts [91], epithelial [92], endothelial [93], and mesenchymal stem cells [94], as well as in cancer cells [95]. The main triggers of cellular senescence can be distinguished into two major categories: development-related and stress-related [96]. While the former is involved in embryo development, wound healing, and tissue remodeling [97], damage-induced senescence is involved in pathological manifestations through the generation of a pro-inflammatory microenvironment [98]. Even though the link between aging and senescence is well-defined, these events are not synonymous. In fact, senescence may occur independently of age in response to detrimental signals [99], such as genotoxic insults [100], oncogenic [101] and oxidative stresses [102], epigenetic modifications, chromatin remodeling [103], imbalanced proteostasis [104], or mitochondrial dysfunction [104]. Each of these signals induces a different type of senescence, identified in accordance to the name of the inducing stressor. Replicative senescence, programmed senescence, and stress-induced premature senescence (SIPS) have been previously described. SIPS includes oncogene-induced senescence (OIS), unresolved DNA damage-induced senescence, epigenetically induced senescence, and mitochondrial dysfunction-associated senescence, as well as therapy-induced senescence (TIS) [105]. Despite a lack of unambiguous markers which are able to define senescent cells, it has been well-accepted that senescent cells share some common features regardless of the type of induction [106]. The main characteristics shared by senescent cells are stable growth arrest, resistance to apoptosis, chromatin remodeling, persistent DNA damage response (DDR), increased activity of senescence associated beta-galactosidase (SA- $\beta$-gal), and the secretion of multiple pro-inflammatory molecules, which are recognized as hallmarks of the senescence-associated secretory phenotype (SASP) $[13,107]$.

\subsection{Markers and Molecular Mechanisms of Senescence}

As a whole, cellular senescence is described as a response to a stress, either endogenous or exogenous. The first mechanism observed in senescent cells, independent of the origin of the trigger, is cell cycle arrest. The activation of p16 or the p53-p21 axis, converging on the transcriptional inactivation of the retinoblastoma protein $(\mathrm{pRb})$, mainly drives the cell cycle blockade [108]. p16 is a small protein that directly interacts with and inhibits cyclin-dependent kinase (CDK) $4 / 6$. It is frequently considered a specific marker of senescence both in vitro and in vivo $[109,110]$. p16 expression, at the transcriptional level, is known to be regulated either by epigenetic changes, such as CDKN2A promoter methylation [111], or by transcription factors, such as PPAR- $\gamma$, Ets, AP1, and Sp [111]. The increased expression of p16 could be balanced by promoter demethylation or by repressor mechanisms, such as INK4A transcription silence element (ITSE), among others. p16 translation is then modulated through the $5^{\prime}$-UTR region and degraded by N-terminus polyubiquitinylation [112].

p21 is another small protein that inhibits different CDKs. Besides being involved in the trigger of cellular senescence, it is also regulated by p53 in the broader context of DDR, and for this reason, it cannot be considered a specific senescence marker. The p53independent regulation of p21 is mainly driven by the TGF- $\beta$ pathway [113]; however, other mechanisms, such as transcriptional repression, control of mRNA stability, phosphorylation, and proteasomal degradation, are known to modulate p21 expression [114]. Moreover, p21 may be indirectly regulated by p16 through the down-regulation of the RNA decaypromoting AUF1 protein [115]. 
Cell cycle arrest is further supported by the activation of DDR pathways, leading, on the one hand, to p16 and p21 activation and p53 phosphorylation and, on the other hand, to nuclear alterations. Histone H2AX phosphorylation is one of the main detectable alterations of senescent cells. Its activation is induced by double-strand DNA breaks (DSBs) through the binding of ATM kinase to the DNA damage site, and it serves to assemble DNA repair complexes [116,117]. Other histone modifications may occur for the same purpose-for instance, the methylation of histone H3 at lysine 9 (H3K9me3) [118]. The detection of gamma-H2AX nuclear foci and p53 phosphorylation indeed are commonly used as markers of senescence, together with p16 and p21 activation [107].

Additionally, some morphological features can be used to identify senescent cellsincreased size and granularity, above all [119]. These morphological parameters may reflect changes in organelle homeostasis and metabolism. Notably, both mitochondria and lysosomes accumulate in senescent cells. Accordingly, increased ROS production, oxidative phosphorylation, and oxygen consumption, as well as lysosomal senescence-associated beta-galactosidase activity, can be assayed to detect senescent cells [120].

\subsection{SASP}

Despite the blockade of cell proliferation, senescent cells remain metabolically active. Accordingly, they secrete a plethora of factors-termed SASP factors-that affect the senescent cell itself as well as non-senescent neighboring cells [121,122]. The exact composition of SASP remains undetermined; however, multiple studies have demonstrated that it is mainly composed of soluble signaling factors, including pro-inflammatory cytokines, chemokines, growth factors, proteases, and matrix metalloproteinases (MMPs), as well as extracellular vesicles [123]. SASP expression is regulated by several pathways, such as nuclear factor $\mathrm{kB}$ (NF-kB), CCAAT-enhancer-binding protein $\beta(C / E B P \beta)$, p38 MAPK, serine-protein kinase ATM, and serine/threonine-protein kinase CHK2, and its composition varies according to the type and duration of the trigger $[124,125]$. In general, DNA damage represents an essential driver of SASP induction [126]. Importantly, SASP factors are not exclusive to senescent cells but may also be expressed by non-senescent ones. CAFs, for example, can secrete factors similar to senescent fibroblasts, being distinguishable from the latter mainly due to their ability to proliferate [16].

The role of SASP in both pathological and physiological processes has been widely identified as dual [99], being potentially beneficial and/or harmful. Many SASP components have immunomodulatory properties [10]. In tumors, for example, interleukin 1 (IL-1), IL-8, and tumor necrosis factor (TNF) are able to recruit immune cells, allowing for the removal of deleterious senescent and neighboring cells in a way that is consistent with the anti-tumor role of senescence [127]. However, the same factors, if chronically expressed, may foster tumor progression, affecting ECM plasticity and vascular permeability [128]. Moreover, SASP factors can also mediate the resistance of senescent cells to immune clearance. Despite the fact that the mechanisms underlying such SASP behaviors have not yet been clearly identified, it is supposed that the accumulation of senescent cells may lead to failed immune clearance and consequent increased SASP production, resulting in boosted senescence induction through the establishment of a feedback loop program $[129,130]$.

Additionally, SASP signaling has been shown to affect the regenerative potential of non-senescent cells [131]. Studies on the regenerative potential of liver cells and keratinocytes in vivo have shown that SASP can affect the regenerative potential through the induction of cell plasticity and stemness [132]. All of these findings have highlighted the complexity and heterogeneity of SASP, thus drawing attention to the necessity of deeply investigating SASP kinetics (Table 1). 
Table 1. Cellular senescence characteristics and biomarkers.

\begin{tabular}{|c|c|c|}
\hline Characteristics & Markers & Ref. \\
\hline Proliferative arrest & $\begin{array}{c}\text { BrDU + } \\
\text { Ki-67 - } \\
\text { pRB inactivation }\end{array}$ & Campisi et al. [133] \\
\hline Persistent DDR activation & $\begin{array}{l}\text { p53, p16, p21 up-regulation } \\
\text { Lamin B1 down-regulation }\end{array}$ & $\begin{array}{l}\text { Gorgoulis et al. [106] } \\
\text { Freund et al. [134] }\end{array}$ \\
\hline Heterochromatic foci & $\begin{array}{l}\text { gamma- } \mathrm{H} 2 \mathrm{AX}+ \\
\text { DAPI staining }\end{array}$ & Funayama et al. [135] \\
\hline Cells flattened and enlarged & Microscopy visible changes & Hernandez-Segura et al. [107] \\
\hline Apoptosis resistance & Bcl-2; Bcl-XL, Bcl-W expression increase & Childs et al. [136] \\
\hline Altered metabolism & $\begin{array}{l}\text { SA- } \beta \text {-gal }+ \\
\text { Lipofuscin }+\end{array}$ & Debacq-Chainaux et al. [137] \\
\hline Organelle dysfunction & $\begin{array}{l}\text { Increased number of mitochondria } \\
\text { Morphological changes } \\
\text { Increased ROS levels }\end{array}$ & Gallage et al. [138] \\
\hline SASP & IL-6; IL-8; MMPs; PAI-1 & Coppe et al. [124] \\
\hline
\end{tabular}

\section{Dual Role of Senescence in PDAC}

As described above, four main mutations (KRAS, CDKN2A, TP53, and SMAD4) progressively accumulate in pancreatic epithelial cells, driving PDAC tumorigenesis. Importantly, those oncogenes and tumor suppressors are deeply related to senescence, supporting the hypothesis of a substantial involvement of this process in controlling malignant transformations. Senescence in PDAC occurs as an early event [2]. Several studies have reported the detection of senescent cells in early-grade PanIN lesions in both mice and humans. In these lesions, cells stained positive for some of the main senescence markers (e.g., SA- $\beta$ gal); showed up-regulation of senescence effectors p16, p53, and p21; and lacked Ki-67 expression $[60,139,140]$. Coherently with these studies, KRAS activation observed in early PanIN lesions has been shown to trigger OIS, a complex senescence program induced in response to oncogenic signaling [141]. Notably, OIS seems to be further enhanced by the concomitant expression increase of $\mathrm{p} 16$ and p53, thus highlighting a protective role of senescence against tumor progression [142]. Despite p16 having been shown to be highly expressed in pancreatic pre-malignancy, frank PDACs displayed inactive p16 in $85 \%$ of cases [143]. This evidence paves the way to the hypothesis of senescence bypass in PDAC, allowing for cancer progression [144]. Consistently with this hypothesis, the long-lasting step-wise development and progression of PDAC, as controlled by OIS, can be overcome by the inactivation of p16, p53, and SMAD4 - events commonly observed in PDAC [144-146]. It is important to note that, while senescence was initially conceived as a stable and irreversible mechanism, its reversibility is now broadly accepted. Several studies have highlighted the inactivation of classical tumor suppressor genes as the most common mechanism for senescence bypass $[147,148]$. Moreover, senescence bypass in PanIN lesions has been related to the inflammation associated with pancreatitis, which is also one of the major risk factors for PDAC development [61,149]. Guerra et al. have demonstrated that pancreatitis-induced inflammation contributes to PanIN development through the inhibition of OIS. Notably, patients treated with anti-inflammatory therapy showed high senescence levels in low-grade PanIN, suggesting the potential use of such therapy to sustain the protective role of OIS [60]. Other mechanisms involved in senescence bypass are the activation of cyclins and cyclin-dependent kinases [150], the de-regulation of downstream effectors of KRAS (i.e., p38-regulated/activated protein kinase (PRAK) and 
AKT) [151,152], PTEN loss [153], and the de-regulation of the mechanisms able to sense DNA damage (e.g., gadd45 proteins) [154], as well as epigenetic modifications [155].

Despite the protective role of OIS in PDAC, accumulating evidence has underpinned the role of sustained and prolonged senescence signaling in tumor progression, mainly due to the pro-inflammatory molecules composing the SASP $[124,156]$. It should be noted that SASP in cancer may play either a pro-tumorigenic or an anti-tumorigenic role. Senescent cells may secrete different factors in variable amounts depending on the type of senescence inducer and on the type of cell undergoing this process. Due to this marked heterogeneity, a common signature to identify SASP-secreting cells is actually lacking. Notwithstanding, a recent study by Jochems et al. has proposed a machine learning-based strategy to detect senescence in in vitro cancer cells [157]. Similarly, Basisty et al. have recently provided the first proteome-based database of SASPs [13]. In general, the main factors secreted by senescent cells include growth factors, such as VEGF, PDGF, HGF, interleukins (IL-1a, IL-6, IL-8, IL-10, IL-13, IL-15), matrix metalloproteinases (MMP3, MMP9), and cytokines/chemokines (CXCL1, CXCL2, CXCL5, CXCL11, CXCL12, CCL2, CCL20). Both tumor and non-tumor cells located in the TME can undergo senescence and are known to secrete different cytokines [158]. In PDAC, as in other inflammatory tumors, the impact of SASP in both tumor and TME evolution remains largely unexplored. Despite this, several SASP molecules, including IL-8, VEGF, and matrix metalloproteinases, have been largely reported in PDAC $[159,160]$. Furthermore, IL-1 $\alpha$ overexpression has been shown to correlate with KRAS mutational status and poor prognosis in PDAC patients [156]. Besides regulating Ras-driven tumorigenesis, IL- $1 \alpha$ also triggers NF- $\mathrm{KB}$ signaling, which is a pivotal mediator of inflammatory responses [161]. Additionally, increased levels of IL-6 expression in PDAC patient serum were correlated with increased disease burden, reduced performance status of patients, and metastases [162,163]. The presence of IL-6 in the TME has been shown to regulate STAT3 activation both in vitro and in vivo, leading to the proposed role of the IL-6/STAT3 program as a driver of PDAC tumorigenesis [164].

\section{Senescence in Non-Tumor Cells}

Senescence is a mechanism inducible in both tumor and non-tumor cells [106]. Importantly, one of the main traits of pancreatic cancer is the presence of abundant stroma, a dynamic system that evolves along with the tumor. Studies on the senescence of PDAC stromal cells have shown PSCs to become senescent after sustained exposure to chemotherapeutic drugs (e.g., doxorubicin) or to oxidizing agents (e.g., $\mathrm{H}_{2} \mathrm{O}_{2}$ ) [165]. Senescent PSCs have shown high CDKN1A expression, together with increased expression of MDM2 and IL-6, while expressing low levels of $\alpha$-SMA. Importantly, in chronic pancreatitis, the number of senescent PSCs was found to be tightly related to inflammation and fibrosis. In particular, in the regions where the immune infiltrate was more abundant, a high amount of fibrotic- and SA $\beta$-Gal-positive cells was detected, thus suggesting a correlation between PSC activation, inflammation, and senescence in the TME. Subsequent studies on rat PSCs have highlighted the key role of CDKN1A in the maintenance of the senescent phenotype of these cells [165]. Additionally, a study from Shao et al. has further confirmed the role of ROS in inducing senescence in PSCs. The authors claimed that the sqstm1-NRF2 axis, which plays a key role in maintaining the ROS balance, modulates the senescent phenotype of PSCs, thus priming tumor progression [166] (Figure 2).

Compared to PSCs, more studies on senescent CAFs have been conducted in PDAC. CAFs represent a significant portion of the PDAC stroma. Several studies have reported the increase of fibrosis and inflammation in the TME following radiotherapy [167]. Interestingly, a study from Ragunathan et al. showed that a radiation dose higher than 10-12 Gy induced senescence in CAFs together with strong DDR activation [168]. Senescent CAFs, like other senescent cells, present a SASP composed of pro-tumorigenic factors, such as IL-6, IL-8, and osteopontin, which are linked to stroma-mediated therapeutic resistance, besides various cytokines related to radiotherapy-induced fibrosis (i.e., TGF- $\beta 1$, TNF- $\alpha$, and IL-1) [169]. In addition, a study from Wang et al. revealed the existence of a senescent CAF population 
in PDAC endowed with invasion- and metastasis-promoting properties mediated by IL-8 overexpression $[170,171]$. These CAFs were found to be correlated with reduced survival in patients with early-stage tumors, pinpointing the possible prognostic significance of senescent CAFs. CAFs also represent the main source of ECM production within the TME. It deserves to be mentioned that the ECM, through changes in its composition, may also influence the level of senescent cells in ageing and diseases [172,173].

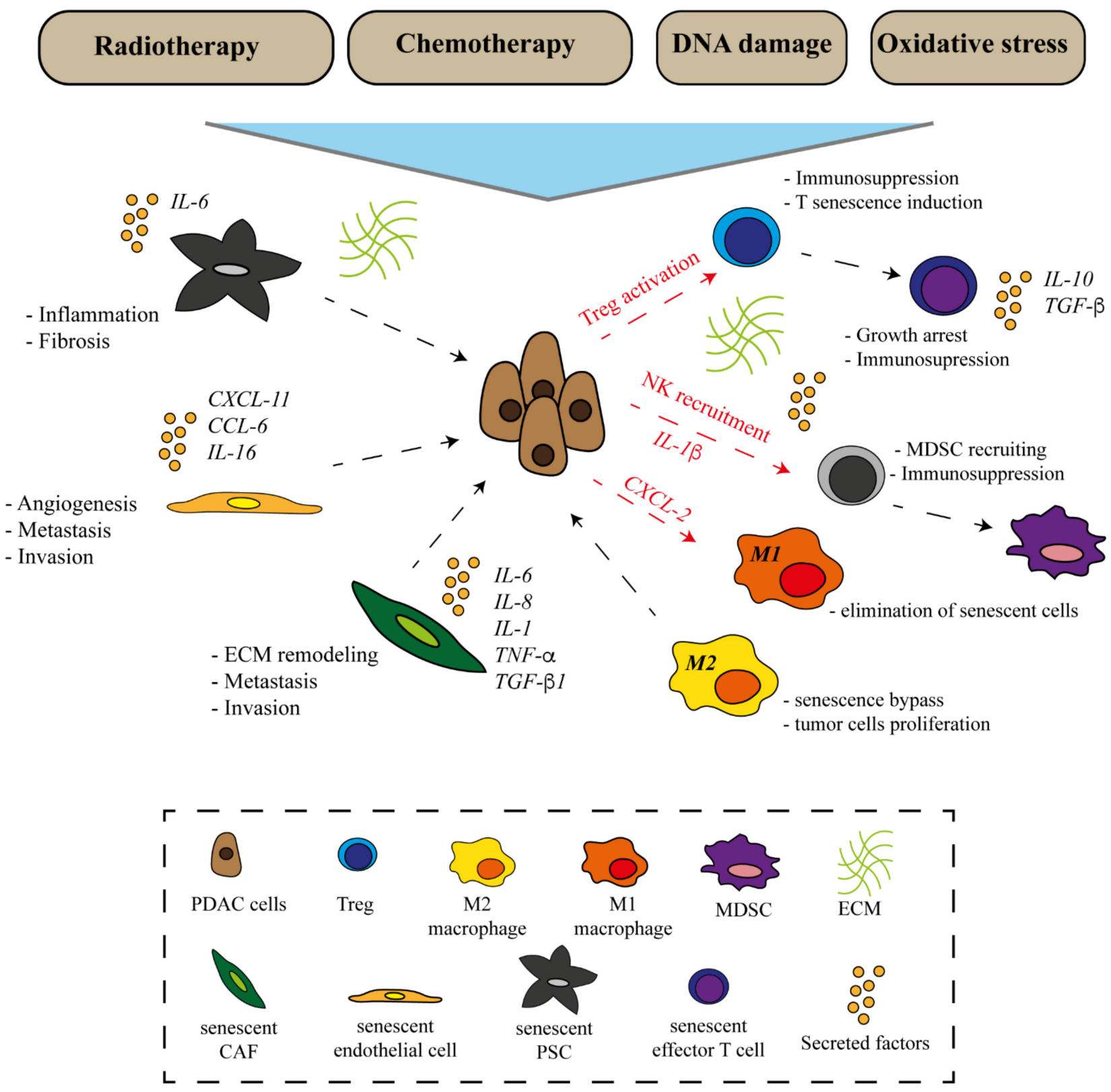

Figure 2. Cross-talk between tumor cells and senescent non-tumor cells in PDAC microenvironment. Abbreviations: PDAC, pancreatic ductal adenocarcinoma; CAF, cancer-associated fibroblast; PSC, pancreatic stellate cell; TAM, tumor-associated macrophage; MDSC, myeloid-derived suppressor cell; Treg, regulatory T cell; ECM, extracellular matrix.

Endothelial cells are important regulators of the development and function of both blood and lymph vessels. Within the TME, their transformation leads to angiogenesis and vessel alterations, contributing to cancer metastasis. A recent study from Hwang et al. has shown that senescence induced by both doxorubicin and ionizing radiation fosters a pro-tumorigenic SASP. In particular, the production of CXCL11 from endothelial cells 
was shown to promote the cell proliferation, migration, and invasion of breast cancer cells in vitro [174]. Similarly, Wang et al. have shown that sunitinib-induced senescence stimulates endothelial cells to secrete pro-inflammatory cytokines, thus promoting cancer metastasis and invasion [175]. In contrast with those studies, Ruscetti et al. have demonstrated that the induction of senescence in PDAC cells, through the use of a combination of palbociclib and trametinib, induced vascular remodeling within the tumor, increasing its sensitivity to cytotoxic drugs and promoting T-cell infiltration [176]. This opposing evidence highlights the necessity of improving the knowledge on the effects of senescence in endothelial cells composing the TME.

\section{Senescence in Immune Cells}

Immune cells infiltrating the tumor deserve a separate discussion. It is well-known that different factors trigger senescence in immune cells, among them thymus degeneration, ageing-related decrease in $\mathrm{T}$ cell function, and inflammation. Additionally, other immune cell-intrinsic and extrinsic factors, such as those derived from the TME, are also involved [177]. In particular, it has been reported that immune cells may be influenced by SASP. Coherently, immune cells' senescence could result from a SASP-driven secondary senescence induced by other senescent tumor and non-tumor cells within the TME [178,179]. As for tumor cells, SASP may modulate the immune system with a dual outcome. On one hand, it may promote an immunosuppressive environment, while on the other hand, it may activate the so-called senescence surveillance, which is able to remove senescent cells [180]. Some studies have shown that tumor cells may exploit the SASP to elude immune surveillance. Senescent tumor cells may induce a TGF- $\beta$-rich SASP, promoting Treg generation and prompting cell-to-cell senescence transmission. Additionally, a study has shown that Tregs induce senescence in naïve and effector T cells modulating p38, ERK1/2 signaling, and cell cycle-regulatory molecules [181]. Senescent T cells, characterized by a loss of CD27 and CD28 expression and by the secretion of molecules such as IL-10 or TGF- $\beta$, have been found to be able to sustain the growth arrest program, supporting the immunosuppressive function of Tregs [182]. Hypoxia within the TME is another factor capable of influencing T cell senescence. A study by Ye et al. has demonstrated that the production of cAMP by tumor cells, induced by the hypoxic environment, is able to trigger senescence in both naïve and effector T cells [182]. Furthermore, tumor cells have also been shown to produce interleukins (e.g., IL-6 and IL-8), which are capable of recruiting myeloid cells that counteract the T cell response [183]. Conversely, senescence surveillance begins when immune cells, such as NKs and macrophages, become activated by the SASP and start to eliminate senescent cells [127]. Chemokines secreted with the SASP, including CCL2, mediate the removal of senescent cells through the NK receptor NKG2D. NK cells are known to be influenced by multiple SASP components [127]. IL-1 $\beta$, for instance, may modulate NK activity with opposite effects depending on the producing cell type. It has been shown that IL-1 $\beta$ secreted by macrophages increases NK cytotoxicity, while IL- $1 \beta$ produced by tumor cells impairs NK cell development and functions, recruiting MDSCs [184,185]. IL-6 and IL-8, other major components of the SASP, have been found to inhibit the cytotoxic activity of NK cells in different tumors through the down-regulation of perforin and Granzyme B [186]. Furthermore, PGE2 secretion in advanced tumors inhibits NK cell activity, while in the early phases of tumorigenesis, it may promote senescence surveillance. Another cell type involved in immune surveillance is macrophages [178]. Macrophages interact with senescent cells, and this interaction is indispensable for major pathophysiological processes [187]. However, the relation between senescent cells and macrophages is controversial; if on one hand, SASP can lead to senescence surveillance through the recruitment of immune cells [187], on the other, senescent cells recruit macrophages, can induce them to undergo senescence, or can influence their polarization. A recent study by Ogata et al. has reported that senescent cells in the dermis are commonly removed by macrophages in a skin ageing model; however, when those cells accumulate over a certain level (e.g., following oxidative stress, UV exposure, or other stresses), the SASP suppresses the macrophage- 
related immune clearance of such cells [188]. Additionally, Covarrubias et al., recently demonstrated that the accumulation of senescent cells promotes an inflammatory state associated with CD38 expression and proliferation in M1-like macrophages. This overexpression, promoted by the SASP, leads to enhanced NADase activity which is known to be related to NAD level decline, a common condition in ageing-related diseases [187]. Furthermore, in a PDAC model, OIS-derived SASP factor CXCL1 leads, on one hand, to M1 macrophage recruitment, thus inhibiting carcinogenesis; meanwhile, on the other hand, M2 macrophages are engaged at late stages together with OIS bypass, thus enhancing tumor proliferation [189]. Such evidence, once again, highlights the dual role of SASP, whose effects depend not only on the cell type involved, but also on the stage of tumorigenesis.

\section{Conclusions and Perspectives}

In the early stages of PDAC development, senescence plays a protective role, hindering oncogenic KRAS activation. However, transformed cells along the process of tumorigenesis continuously fight to tackle senescence. Although the mechanisms leading to senescence bypass still remain to be clarified, the acquisition of loss-of-function mutations in tumor suppressor genes, such as TP53, CDKN2A, and SMAD4, leads to the establishment of a highly aggressive tumor [190]. Multiple studies have reported that senescence increases in normal tissues can be connected to tumor progression, thus highlighting a potential role of the senescent stroma in supporting age-related cancers [11]. However, senescence in non-tumor cells is not only related to ageing; DNA damage and oxidative stress caused by systemic cancer therapies are known to trigger senescence in normal cells [55]. Evidence for this has come from patients receiving radio- or chemotherapy showing accelerated biological ageing [185] and from survivors of childhood cancers having an increased risk of developing secondary tumors [191]. For PDAC patients, beyond surgery, the most effective treatment option is represented by systemic chemotherapy, which is administered in all eligible patients, independent of tumor stage, genetic, and histological characteristics [192]. Such wide use of chemotherapy has a valuable effect not only on tumor cells, but also on the cells composing the TME. Although therapy-induced senescence is generally considered a favorable event for patient prognoses, the persistence of senescent cells has been shown to increase the risk of oncogenic transformation and to impair tissue functions. Interestingly, it has been reported that the elimination of senescent cells prevents or mitigates senescencerelated diseases $[157,177,193]$. Strategies to target senescence in cancer have emerged in the pharmacological panorama. In particular, an innovative "one-two punch" approach could pave the way for the use of senotherapeutics in cancer treatment. This approach consists of senescence induction in both tumor and non-tumor cells through the administration of anti-cancer drugs at clinical doses followed by a senotherapeutic drug which selectively eliminates senescent cells. In this way, on one hand, tumor progression, relapse, and drug resistance could be prevented, thus avoiding the detrimental accumulation of senescent cells within the tumor; meanwhile, on the other hand, therapeutic side effects may be alleviated by removing the senescent cells from normal tissue. Despite the great promise of this approach, several issues remain to be addressed to allow for the clinical use of senotherapeutics. First of all, an unambiguous senescence signature allowing senescence targeting in vivo is needed, together with appropriate models representing tumor heterogeneity and $3 \mathrm{D}$ architecture exploitable for the development of such drugs.

To conclude, cellular senescence presents a dual function in PDAC which is dependent on the stage of tumorigenesis and the cell type involved. During PDAC establishment, nontumor cells in normal tissue evolve together with cancer cells, and the cross-talk between tumor cells and TME contribute to the disease outcome. Therefore, the shift from a tumor cell-centric view to a deep knowledge of TME biology is necessary for the development of new and effective therapies against PDAC. Additionally, the progress made in molecular diagnosis regarding circulating proteins, miRNAs, or vesicles may open new scenarios for early diagnosis of PDAC. One of the main advantages of molecular techniques is the noninvasiveness. Tumor-derived SASP, and potentially also proteins derived from senescent 
non-malignant cells, can be detected and monitored over time in blood, pancreatic juice, or other biological fluids and may be investigated as a useful tool for early diagnosis of PC. In light of this evidence, therapeutic senescence modulation may represent a valuable strategy for the treatment of PDAC.

Author Contributions: Conceptualization, M.C. and S.B.; writing-original draft preparation, M.C.; writing-review and editing, M.C., M.Z., F.P., M.M.T., S.R., I.G.R., G.L.F. and S.B. All authors have read and agreed to the published version of the manuscript.

Funding: This research received no external funding.

Institutional Review Board Statement: Not applicable.

Informed Consent Statement: Not applicable.

Acknowledgments: The authors thank Tom McCone for English editing.

Conflicts of Interest: The authors declare no conflict of interest.

\section{References}

1. Siegel, R.L.; Miller, K.D.; Jemal, A. Cancer statistics. CA. Cancer J. Clin. 2020, 70, 7-30. [CrossRef] [PubMed]

2. Porciuncula, A.; Hajdu, C.; David, G. The Dual Role of Senescence in Pancreatic Ductal Adenocarcinoma. Adv. Cancer Res. 2016, 131, 1-20. [CrossRef] [PubMed]

3. Kleeff, J.; Korc, M.; Apte, M.; La Vecchia, C.; Johnson, C.D.; Biankin, A.V.; Neale, R.E.; Tempero, M.; Tuveson, D.A.; Hruban, R.H.; et al. Pancreatic cancer. Nat. Rev. Dis. Prim. 2016, 2, 16022. [CrossRef] [PubMed]

4. Gheorghe, G.; Bungau, S.; Ilie, M.; Behl, T.; Vesa, C.M.; Brisc, C.; Bacalbasa, N.; Turi, V.; Costache, R.S.; Diaconu, C.C. Early Diagnosis of Pancreatic Cancer: The Key for Survival. Diagnostics 2020, 10, 869. [CrossRef]

5. Gutiérrez, M.L.; Muñoz-Bellvís, L.; Orfao, A. Genomic Heterogeneity of Pancreatic Ductal Adenocarcinoma and Its Clinical Impact. Cancers 2021, 13, 4451. [CrossRef]

6. Veenstra, V.L.; Garcia-Garijo, A.; Van Laarhoven, H.W.; Bijlsma, M.F. Extracellular Influences: Molecular Subclasses and the Microenvironment in Pancreatic Cancer. Cancers 2018, 10, 34. [CrossRef]

7. Apte, M.V.; Park, S.; Phillips, P.A.; Santucci, N.; Goldstein, D.; Kumar, R.K.; Ramm, G.A.; Buchler, M.; Friess, H.; McCarroll, J.A.; et al. Desmoplastic reaction in pancreatic cancer: Role of pancreatic stellate cells. Pancreas 2004, 29, 179-187. [CrossRef]

8. Lu, P.; Weaver, V.M.; Werb, Z. The extracellular matrix: A dynamic niche in cancer progression. J. Cell Biol. 2012, 196, 395-406. [CrossRef]

9. Bernadotte, A.; Mikhelson, V.M.; Spivak, I.M. Markers of cellular senescence. Telomere shortening as a marker of cellular senescence. Aging 2016, 8, 3-11. [CrossRef]

10. Muñoz-Espín, D.; Serrano, M. Cellular senescence: From physiology to pathology. Nat. Rev. Mol. Cell Biol. 2014, 15, 482-496. [CrossRef]

11. Campisi, J. Aging, cellular senescence, and cancer. Annu. Rev. Physiol. 2013, 75, 685-705. [CrossRef]

12. Prasanna, P.G.; Citrin, D.E.; Hildesheim, J.; Ahmed, M.M.; Venkatachalam, S.; Riscuta, G.; Xi, D.; Zheng, G.; van Deursen, J.; Goronzy, J.; et al. Therapy-Induced Senescence: Opportunities to Improve Anticancer Therapy. J. Natl. Cancer Inst. 2021, 113, 1285-1298. [CrossRef]

13. Basisty, N.; Kale, A.; Jeon, O.H.; Kuehnemann, C.; Payne, T.; Rao, C.; Holtz, A.; Shah, S.; Sharma, V.; Ferrucci, L.; et al. A proteomic atlas of senescence-associated secretomes for aging biomarker development. PLoS Biol. 2020, 18, e3000599. [CrossRef]

14. Sharpless, N.E.; Sherr, C.J. Forging a signature of in vivo senescence. Nat. Rev. Cancer 2015, 15, 397-408. [CrossRef]

15. Lau, L.; David, G. Pro- and anti-tumorigenic functions of the senescence-associated secretory phenotype. Expert Opin. Ther. Targets 2019, 23, 1041-1051. [CrossRef]

16. Faget, D.V.; Ren, Q.; Stewart, S.A. Unmasking senescence: Context-dependent effects of SASP in cancer. Nat. Rev. Cancer 2019, 19, 439-453. [CrossRef]

17. Schmitt, C.A.; Fridman, J.S.; Yang, M.; Lee, S.; Baranov, E.; Hoffman, R.M.; Lowe, S.W. A senescence program controlled by p53 and p16INK4a contributes to the outcome of cancer therapy. Cell 2002, 109, 335-346. [CrossRef]

18. Kanda, M.; Matthaei, H.; Wu, J.; Hong, S.M.; Yu, J.; Borges, M.; Hruban, R.H.; Maitra, A.; Kinzler, K.; Vogelstein, B.; et al. Presence of somatic mutations in most early-stage pancreatic intraepithelial neoplasia. Gastroenterology 2012, 142, 730-733. [CrossRef]

19. Singh, M.; Maitra, A. Precursor lesions of pancreatic cancer: Molecular pathology and clinical implications. Pancreatology 2007, 7, 9-19. [CrossRef]

20. Hayashi, H.; Higashi, T.; Miyata, T.; Yamashita, Y.; Baba, H. Recent advances in precision medicine for pancreatic ductal adenocarcinoma. Ann. Gastroenterol. Surg. 2021, 5, 457-466. [CrossRef]

21. Buscail, L.; Bournet, B.; Cordelier, P. Role of oncogenic KRAS in the diagnosis, prognosis and treatment of pancreatic cancer. Nat. Rev. Gastroenterol. Hepatol. 2020, 17, 153-168. [CrossRef]

22. Mizrahi, J.D.; Surana, R.; Valle, J.W.; Shroff, R.T. Pancreatic cancer. Lancet 2020, 395, 2008-2020. [CrossRef] 
23. Dardare, J.; Witz, A.; Merlin, J.L.; Gilson, P.; Harlé, A. SMAD4 and the TGF $\beta$ Pathway in Patients with Pancreatic Ductal Adenocarcinoma. Int. J. Mol. Sci. 2020, 21, 3534. [CrossRef]

24. Waddell, N.N.; Pajic, M.; Patch, A.M.; Chang, D.K.; Kassahn, K.S.; Bailey, P.; Johns, A.L.; Miller, D.; Nones, K.; Quek, K.; et al Whole genomes redefine the mutational landscape of pancreatic cancer. Nature 2015, 518, 495-501. [CrossRef]

25. Connor, A.A.; Denroche, R.E.; Jang, G.H.; Lemire, M.; Zhang, A.; Chan-Seng-Yue, M.; Wilson, G.; Grant, R.C.; Merico, D.; Lungu, I.; et al. Integration of Genomic and Transcriptional Features in Pancreatic Cancer Reveals Increased Cell Cycle Progression in Metastases. Cancer Cell 2019, 35, 267.e7-282.e7. [CrossRef]

26. Ying, H.; Dey, P.; Yao, W.; Kimmelman, A.C.; Draetta, G.F.; Maitra, A.; Depinho, R.A. Genetics and biology of pancreatic ductal adenocarcinoma. Genes Dev. 2016, 30, 355-385. [CrossRef]

27. Samuel, N.; Hudson, T.J. The molecular and cellular heterogeneity of pancreatic ductal adenocarcinoma. Nat. Rev. Gastroenterol. Hepatol. 2011, 9, 77-87. [CrossRef]

28. Iguchi, E.; Safgren, S.L.; Marks, D.L.; Olson, R.L.; Fernandez-Zapico, M.E. Pancreatic cancer, a Mis-interpreter of the epigenetic language. Yale J. Biol. Med. 2016, 89, 575-590. [CrossRef]

29. Hung, Y.H.; Hsu, M.C.; Chen, L.T.; Hung, W.C.; Pan, M.R. Alteration of Epigenetic Modifiers in Pancreatic Cancer and Its Clinical Implication. J. Clin. Med. 2019, 8, 903. [CrossRef]

30. Kadaba, R.; Birke, H.; Wang, J.; Hooper, S.; Andl, C.D.; Di Maggio, F.; Soylu, E.; Ghallab, M.; Bor, D.; Froeling, F.E.M.; et al. Imbalance of desmoplastic stromal cell numbers drives aggressive cancer processes. J. Pathol. 2013, 230, 107-117. [CrossRef]

31. Whatcott, C.J.; Diep, C.H.; Jiang, P.; Watanabe, A.; Lobello, J.; Sima, C.; Hostetter, G.; Shepard, H.M.; Von Hoff, D.D.; Han, H. Desmoplasia in Primary Tumors and Metastatic Lesions of Pancreatic Cancer. Clin. Cancer Res. 2015, 21, 3561-3568. [CrossRef] [PubMed]

32. Vonlaufen, A.; Joshi, S.; Qu, C.; Phillips, P.A.; Xu, Z.; Parker, N.R.; Toi, C.S.; Pirola, R.C.; Wilson, J.S.; Goldstein, D.; et al. Pancreatic stellate cells: Partners in crime with pancreatic cancer cells. Cancer Res. 2008, 68, 2085-2093. [CrossRef] [PubMed]

33. Balkwill, F.R.; Capasso, M.; Hagemann, T. The tumor microenvironment at a glance. J. Cell Sci. 2012, 125, 5591-5596. [CrossRef] [PubMed]

34. Ansari, D.; Carvajo, M.; Bauden, M.; Andersson, R. Pancreatic cancer stroma: Controversies and current insights. Scand. J. Gastroenterol. 2017, 52, 641-646. [CrossRef]

35. Allam, A.; Thomsen, A.R.; Gothwal, M.; Saha, D.; Maurer, J.; Brunner, T.B. Pancreatic stellate cells in pancreatic cancer: In focus. Pancreatology 2017, 17, 514-522. [CrossRef]

36. Fu, Y.; Liu, S.; Zeng, S.; Shen, H. The critical roles of activated stellate cells-mediated paracrine signaling, metabolism and onco-immunology in pancreatic ductal adenocarcinoma. Mol. Cancer 2018, 17, 62. [CrossRef]

37. Schnittert, J.; Bansal, R.; Prakash, J. Targeting Pancreatic Stellate Cells in Cancer. Trends Cancer 2019, 5, 128-142. [CrossRef]

38. Apte, M.V.; Wilson, J.S.; Lugea, A.; Pandol, S.J. A starring role for stellate cells in the pancreatic cancer microenvironment. Gastroenterology 2013, 144, 1210-1219. [CrossRef]

39. Lugea, A.; Waldron, R.T. Exosome-Mediated Intercellular Communication Between Stellate Cells and Cancer Cells in Pancreatic Ductal Adenocarcinoma. Pancreas 2017, 46, 1-4. [CrossRef]

40. Sousa, C.M.; Biancur, D.E.; Wang, X.; Halbrook, C.J.; Sherman, M.H.; Zhang, L.; Kremer, D.; Hwang, R.F.; Witkiewicz, A.K.; Ying, H.; et al. Pancreatic stellate cells support tumour metabolism through autophagic alanine secretion. Nature 2016, 536, 479-483. [CrossRef]

41. Kota, J.; Hancock, J.; Kwon, J.; Korc, M. Pancreatic cancer: Stroma and its current and emerging targeted therapies. Cancer Lett. 2017, 391, 38-49. [CrossRef]

42. Nagathihalli, N.S.; Castellanos, J.A.; Van Saun, M.N.; Dai, X.; Ambrose, M.; Guo, Q.; Xiong, Y.; Merchant, N.B. Pancreatic stellate cell secreted IL-6 stimulates STAT3 dependent invasiveness of pancreatic intraepithelial neoplasia and cancer cells. Oncotarget 2016, 7, 65982-65992. [CrossRef]

43. Berchtold, S.; Grünwald, B.; Krüger, A.; Reithmeier, A.; Hähl, T.; Cheng, T.; Feuchtinger, A.; Born, D.; Erkan, M.; Kleeff, J.; et al. Collagen type V promotes the malignant phenotype of pancreatic ductal adenocarcinoma. Cancer Lett. 2015, 356, 721-732. [CrossRef]

44. Di Maggio, F.; Arumugam, P.; Delvecchio, F.R.; Batista, S.; Lechertier, T.; Hodivala-Dilke, K.; Kocher, H.M. Pancreatic stellate cells regulate blood vessel density in the stroma of pancreatic ductal adenocarcinoma. Pancreatology 2016, 16, 995-1004. [CrossRef]

45. Ferrara, B.; Pignatelli, C.; Cossutta, M.; Citro, A.; Courty, J.; Piemonti, L. The Extracellular Matrix in Pancreatic Cancer: Description of a Complex Network and Promising Therapeutic Options. Cancers 2021, 13, 4442. [CrossRef]

46. Tang, D.; Wang, D.; Yuan, Z.; Xue, X.; Zhang, Y.; An, Y.; Chen, J.; Tu, M.; Lu, Z.; Wei, J.; et al. Persistent activation of pancreatic stellate cells creates a microenvironment favorable for the malignant behavior of pancreatic ductal adenocarcinoma. Int. J. cancer 2013, 132, 993-1003. [CrossRef]

47. Sahai, E.; Astsaturov, I.; Cukierman, E.; DeNardo, D.G.; Egeblad, M.; Evans, R.M.; Fearon, D.; Greten, F.R.; Hingorani, S.R.; Hunter, T.; et al. A framework for advancing our understanding of cancer-associated fibroblasts. Nat. Rev. Cancer 2020, 20, 174-186. [CrossRef]

48. Nielsen, M.F.B.; Mortensen, M.B.; Detlefsen, S. Key players in pancreatic cancer-stroma interaction: Cancer-associated fibroblasts, endothelial and inflammatory cells. World J. Gastroenterol. 2016, 22, 2678-2700. [CrossRef] 
49. Pothula, S.P.; Xu, Z.; Goldstein, D.; Pirola, R.C.; Wilson, J.S.; Apte, M.V. Key role of pancreatic stellate cells in pancreatic cancer. Cancer Lett. 2016, 381, 194-200. [CrossRef]

50. Von Ahrens, D.; Bhagat, T.D.; Nagrath, D.; Maitra, A.; Verma, A. The role of stromal cancer-associated fibroblasts in pancreatic cancer. J. Hematol. Oncol. 2017, 10, 76. [CrossRef]

51. Sanz-Moreno, V.; Gaggioli, C.; Yeo, M.; Albrengues, J.; Wallberg, F.; Viros, A.; Hooper, S.; Mitter, R.; Féral, C.C.; Cook, M.; et al. ROCK and JAK1 signaling cooperate to control actomyosin contractility in tumor cells and stroma. Cancer Cell 2011, 20, 229-245. [CrossRef]

52. Malik, R.; Luong, T.; Cao, X.; Han, B.; Shah, N.; Franco-Barraza, J.; Han, L.; Shenoy, V.B.; Lelkes, P.I.; Cukierman, E. Rigidity controls human desmoplastic matrix anisotropy to enable pancreatic cancer cell spread via extracellular signal-regulated kinase 2. Matrix Biol. 2019, 81, 50-69. [CrossRef]

53. Avery, D.; Govindaraju, P.; Jacob, M.; Todd, L.; Monslow, J.; Puré, E. Extracellular matrix directs phenotypic heterogeneity of activated fibroblasts. Matrix Biol. 2018, 67, 90-106. [CrossRef]

54. Strell, C.; Paulsson, J.; Jin, S.B.; Tobin, N.P.; Mezheyeuski, A.; Roswall, P.; Mutgan, C.; Mitsios, N.; Johansson, H.; Wickberg, S.M.; et al. Impact of Epithelial-Stromal Interactions on Peritumoral Fibroblasts in Ductal Carcinoma in Situ. J. Natl. Cancer Inst. 2019, 111, 983-995. [CrossRef]

55. Demaria, M.; O’Leary, M.N.; Chang, J.; Shao, L.; Liu, S.; Alimirah, F.; Koenig, K.; Le, C.; Mitin, N.; Deal, A.M.; et al. Cellular Senescence Promotes Adverse Effects of Chemotherapy and Cancer Relapse. Cancer Discov. 2017, 7, 165-176. [CrossRef]

56. Shindo, K.; Aishima, S.; Ohuchida, K.; Fujiwara, K.; Fujino, M.; Mizuuchi, Y.; Hattori, M.; Mizumoto, K.; Tanaka, M.; Oda, Y. Podoplanin expression in cancer-associated fibroblasts enhances tumor progression of invasive ductal carcinoma of the pancreas. Mol. Cancer 2013, 12, 168. [CrossRef]

57. Hwang, R.F.; Moore, T.; Arumugam, T.; Ramachandran, V.; Amos, K.D.; Rivera, A.; Ji, B.; Evans, D.B.; Logsdon, C.D. Cancerassociated stromal fibroblasts promote pancreatic tumor progression. Cancer Res. 2008, 68, 918-926. [CrossRef]

58. Rhim, A.D.; Oberstein, P.E.; Thomas, D.H.; Mirek, E.T.; Palermo, C.F.; Sastra, S.A.; Dekleva, E.N.; Saunders, T.; Becerra, C.P.; Tattersall, I.W.; et al. Stromal elements act to restrain, rather than support, pancreatic ductal adenocarcinoma. Cancer Cell 2014, 25, 735-747. [CrossRef]

59. Öhlund, D.; Handly-Santana, A.; Biffi, G.; Elyada, E.; Almeida, A.S.; Ponz-Sarvise, M.; Corbo, V.; Oni, T.E.; Hearn, S.A.; Lee, E.J.; et al. Distinct populations of inflammatory fibroblasts and myofibroblasts in pancreatic cancer. J. Exp. Med. 2017, 214, 579-596. [CrossRef]

60. Guerra, C.; Collado, M.; Navas, C.; Schuhmacher, A.J.; Hernández-Porras, I.; Cañamero, M.; Rodriguez-Justo, M.; Serrano, M.; Barbacid, M. Pancreatitis-induced inflammation contributes to pancreatic cancer by inhibiting oncogene-induced senescence. Cancer Cell 2011, 19, 728-739. [CrossRef]

61. Yadav, D.; Lowenfels, A.B. The epidemiology of pancreatitis and pancreatic cancer. Gastroenterology 2013, $144,1252-1261$. [CrossRef] [PubMed]

62. Ho, W.J.; Jaffee, E.M.; Zheng, L. The tumour microenvironment in pancreatic cancer-clinical challenges and opportunities. Nat. Rev. Clin. Oncol. 2020, 17, 527-540. [CrossRef] [PubMed]

63. Bettelli, E.; Carrier, Y.; Gao, W.; Korn, T.; Strom, T.B.; Oukka, M.; Weiner, H.L.; Kuchroo, V.K. Reciprocal developmental pathways for the generation of pathogenic effector TH17 and regulatory T cells. Nature 2006, 441, 235-238. [CrossRef] [PubMed]

64. Tang, Y.; Xu, X.; Guo, S.; Zhang, C.; Tang, Y.; Tian, Y.; Ni, B.; Lu, B.; Wang, H. An increased abundance of tumor-infiltrating regulatory $\mathrm{T}$ cells is correlated with the progression and prognosis of pancreatic ductal adenocarcinoma. PLoS ONE 2014, 9, e91551. [CrossRef]

65. Moon, Y.W.; Hajjar, J.; Hwu, P.; Naing, A. Targeting the indoleamine 2,3-dioxygenase pathway in cancer. J. Immunother. Cancer 2015, 3, 51. [CrossRef]

66. Bulle, A.; Lim, K.H. Beyond just a tight fortress: Contribution of stroma to epithelial-mesenchymal transition in pancreatic cancer. Signal Transduct. Target. Ther. 2020, 5, 249. [CrossRef]

67. Markowitz, J.; Brooks, T.R.; Duggan, M.C.; Paul, B.K.; Pan, X.; Wei, L.; Abrams, Z.; Luedke, E.; Lesinski, G.B.; Mundy-Bosse, B.; et al. Patients with pancreatic adenocarcinoma exhibit elevated levels of myeloid-derived suppressor cells upon progression of disease. Cancer Immunol. Immunother. 2015, 64, 149-159. [CrossRef]

68. Bayne, L.J.; Beatty, G.L.; Jhala, N.; Clark, C.E.; Rhim, A.D.; Stanger, B.Z.; Vonderheide, R.H. Tumor-derived granulocytemacrophage colony-stimulating factor regulates myeloid inflammation and T cell immunity in pancreatic cancer. Cancer Cell 2012, 21, 822-835. [CrossRef]

69. Otsuji, M.; Kimura, Y.; Aoe, T.; Okamoto, Y.; Saito, T. Oxidative stress by tumor-derived macrophages suppresses the expression of CD3 zeta chain of T-cell receptor complex and antigen-specific T-cell responses. Proc. Natl. Acad. Sci. USA 1996, 93, 13119-13124. [CrossRef]

70. Stromnes, I.M.; Brockenbrough, J.S.; Izeradjene, K.; Carlson, M.A.; Cuevas, C.; Simmons, R.M.; Greenberg, P.D.; Hingorani, S.R. Targeted depletion of an MDSC subset unmasks pancreatic ductal adenocarcinoma to adaptive immunity. Gut 2014, 63, 1769-1781. [CrossRef]

71. Lee, C.; Jeong, H.; Bae, Y.; Shin, K.; Kang, S.; Kim, H.; Oh, J.; Bae, H. Targeting of M2-like tumor-associated macrophages with a melittin-based pro-apoptotic peptide. J. Immunother. Cancer 2019, 7, 147. [CrossRef] 
72. Solinas, G.; Germano, G.; Mantovani, A.; Allavena, P. Tumor-associated macrophages (TAM) as major players of the cancer-related inflammation. J. Leukoc. Biol. 2009, 86, 1065-1073. [CrossRef]

73. Hao, N.B.; Lü, M.H.; Fan, Y.H.; Cao, Y.L.; Zhang, Z.R.; Yang, S.M. Macrophages in tumor microenvironments and the progression of tumors. Clin. Dev. Immunol. 2012, 2012, 948098. [CrossRef]

74. Rodriguez, P.C.; Quiceno, D.G.; Zabaleta, J.; Ortiz, B.; Zea, A.H.; Piazuelo, M.B.; Delgado, A.; Correa, P.; Brayer, J.; Sotomayor, E.M.; et al. Arginase I production in the tumor microenvironment by mature myeloid cells inhibits T-cell receptor expression and antigen-specific T-cell responses. Cancer Res. 2004, 64, 5839-5849. [CrossRef]

75. Xue, J.; Sharma, V.; Hsieh, M.H.; Chawla, A.; Murali, R.; Pandol, S.J.; Habtezion, A. Alternatively activated macrophages promote pancreatic fibrosis in chronic pancreatitis. Nat. Commun. 2015, 6, 7158. [CrossRef]

76. Elaileh, A.; Saharia, A.; Potter, L.; Baio, F.; Ghafel, A.; Abdelrahim, M.; Heyne, K. Promising new treatments for pancreatic cancer in the era of targeted and immune therapies. Am. J. Cancer Res. 2019, 9, 1871-1888.

77. Qian, J.; Olbrecht, S.; Boeckx, B.; Vos, H.; Laoui, D.; Etlioglu, E.; Wauters, E.; Pomella, V.; Verbandt, S.; Busschaert, P.; et al. A pan-cancer blueprint of the heterogeneous tumor microenvironment revealed by single-cell profiling. Cell Res. 2020, 30, 745-762. [CrossRef]

78. Büchler, P.; Reber, H.A.; Büchler, M.; Shrinkante, S.; Büchler, M.W.; Friess, H.; Semenza, G.L.; Hines, O.J. Hypoxia-inducible factor 1 regulates vascular endothelial growth factor expression in human pancreatic cancer. Pancreas 2003, 26, 56-64. [CrossRef]

79. Erkan, M.; Reiser-Erkan, C.; Michalski, C.W.; Deucker, S.; Sauliunaite, D.; Streit, S.; Esposito, I.; Friess, H.; Kleeff, J. Cancer-stellate cell interactions perpetuate the hypoxia-fibrosis cycle in pancreatic ductal adenocarcinoma. Neoplasia 2009, 11, 497-508. [CrossRef]

80. Korc, M. Pathways for aberrant angiogenesis in pancreatic cancer. Mol. Cancer 2003, 2, 8. [CrossRef]

81. Lonardo, E.; Hermann, P.C.; Mueller, M.T.; Huber, S.; Balic, A.; Miranda-Lorenzo, I.; Zagorac, S.; Alcala, S.; Rodriguez-Arabaolaza, I.; Ramirez, J.C.; et al. Nodal/Activin signaling drives self-renewal and tumorigenicity of pancreatic cancer stem cells and provides a target for combined drug therapy. Cell Stem Cell 2011, 9, 433-446. [CrossRef]

82. Hou, Y.C.; Chao, Y.J.; Tung, H.L.; Wang, H.C.; Shan, Y.S. Coexpression of CD44-positive/CD133-positive cancer stem cells and CD204-positive tumor-associated macrophages is a predictor of survival in pancreatic ductal adenocarcinoma. Cancer 2014, 120, 2766-2777. [CrossRef]

83. Onishi, H.; Katano, M. Hedgehog signaling pathway as a new therapeutic target in pancreatic cancer. World J. Gastroenterol. 2014, 20, 2335-2342. [CrossRef]

84. Theocharis, A.D.; Skandalis, S.S.; Gialeli, C.; Karamanos, N.K. Extracellular matrix structure. Adv. Drug Deliv. Rev. 2016, 97, 4-27. [CrossRef] [PubMed]

85. Tian, C.; Clauser, K.R.; Öhlund, D.; Rickelt, S.; Huang, Y.; Gupta, M.; Mani, D.R.; Carr, S.A.; Tuveson, D.A.; Hynes, R.O. Proteomic analyses of ECM during pancreatic ductal adenocarcinoma progression reveal different contributions by tumor and stromal cells. Proc. Natl. Acad. Sci. USA 2019, 116, 19609-19618. [CrossRef] [PubMed]

86. Paszek, M.J.; Zahir, N.; Johnson, K.R.; Lakins, J.N.; Rozenberg, G.I.; Gefen, A.; Reinhart-King, C.A.; Margulies, S.S.; Dembo, M.; Boettiger, D.; et al. Tensional homeostasis and the malignant phenotype. Cancer Cell 2005, 8, 241-254. [CrossRef] [PubMed]

87. Cooper, J.; Giancotti, F.G. Integrin Signaling in Cancer: Mechanotransduction, Stemness, Epithelial Plasticity, and Therapeutic Resistance. Cancer Cell 2019, 35, 347-367. [CrossRef]

88. Schaffner, F.; Ray, A.M.; Dontenwill, M. Integrin $\alpha 5 \beta 1$, the Fibronectin Receptor, as a Pertinent Therapeutic Target in Solid Tumors. Cancers 2013, 5, 27-47. [CrossRef]

89. Jacobetz, M.A.; Chan, D.S.; Neesse, A.; Bapiro, T.E.; Cook, N.; Frese, K.K.; Feig, C.; Nakagawa, T.; Caldwell, M.E.; Zecchini, H.I.; et al. Hyaluronan impairs vascular function and drug delivery in a mouse model of pancreatic cancer. Gut 2013, 62, 112-120. [CrossRef]

90. Hayflick, L.; Moorhead, P.S. The serial cultivation of human diploid cell strains. Exp. Cell Res. 1961, 25, 585-621. [CrossRef]

91. Krtolica, A.; Parrinello, S.; Lockett, S.; Desprez, P.Y.; Campisi, J. Senescent fibroblasts promote epithelial cell growth and tumorigenesis: A link between cancer and aging. Proc. Natl. Acad. Sci. USA 2001, 98, 12072-12077. [CrossRef]

92. Abbadie, C.; Pluquet, O.; Pourtier, A. Epithelial cell senescence: An adaptive response to pre-carcinogenic stresses? Cell. Mol. Life Sci. 2017, 74, 4471-4509. [CrossRef]

93. Erusalimsky, J.D.; Kurz, D.J. Endothelial cell senescence. Handb. Exp. Pharmacol. 2006, 176, 213-248. [CrossRef]

94. Liu, J.; Ding, Y.; Liu, Z.; Liang, X. Senescence in Mesenchymal Stem Cells: Functional Alterations, Molecular Mechanisms, and Rejuvenation Strategies. Front. Cell Dev. Biol. 2020, 8, 258. [CrossRef]

95. Zeng, S.; Shen, W.H.; Liu, L. Senescence and Cancer. Cancer Transl. Med. 2018, 4, 70. [CrossRef]

96. Paez-Ribes, M.; González-Gualda, E.; Doherty, G.J.; Muñoz-Espín, D. Targeting senescent cells in translational medicine. EMBO Mol. Med. 2019, 11, e10234. [CrossRef]

97. Rhinn, M.; Ritschka, B.; Keyes, W.M. Cellular senescence in development, regeneration and disease. Development 2019, 146, dev151837. [CrossRef]

98. Van Deursen, J.M. The role of senescent cells in ageing. Nature 2014, 509, 439-446. [CrossRef]

99. Rodier, F.; Campisi, J. Four faces of cellular senescence. J. Cell Biol. 2011, 192, 547-556. [CrossRef]

100. Kuilman, T.; Michaloglou, C.; Mooi, W.J.; Peeper, D.S. The essence of senescence. Genes Dev. 2010, 24, 2463-2479. [CrossRef] 
101. Di Micco, R.; Fumagalli, M.; Cicalese, A.; Piccinin, S.; Gasparini, P.; Luise, C.; Schurra, C.; Garré, M.; Giovanni Nuciforo, P.; Bensimon, A.; et al. Oncogene-induced senescence is a DNA damage response triggered by DNA hyper-replication. Nature 2006, 444, 638-642. [CrossRef]

102. Nakamura, A.J.; Chiang, Y.J.; Hathcock, K.S.; Horikawa, I.; Sedelnikova, O.A.; Hodes, R.J.; Bonner, W.M. Both telomeric and non-telomeric DNA damage are determinants of mammalian cellular senescence. Epigenet. Chromatin 2008, 1, 6-12. [CrossRef]

103. Pazolli, E.; Alspach, E.; Milczarek, A.; Prior, J.; Piwnica-Worms, D.; Stewart, S.A. Chromatin remodeling underlies the senescenceassociated secretory phenotype of tumor stromal fibroblasts that supports cancer progression. Cancer Res. 2012, 72, $2251-2261$. [CrossRef]

104. Pluquet, O.; Pourtier, A.; Abbadie, C. The unfolded protein response and cellular senescence. A review in the theme: Cellular mechanisms of endoplasmic reticulum stress signaling in health and disease. Am. J. Physiol. Cell Physiol. 2015, 308, 415-425. [CrossRef]

105. Campisi, J. Cancer, aging and cellular senescence. Vivo 2000, 14, 183-188.

106. Gorgoulis, V.; Adams, P.D.; Alimonti, A.; Bennett, D.C.; Bischof, O.; Bishop, C.; Campisi, J.; Collado, M.; Evangelou, K.; Ferbeyre, G.; et al. Cellular Senescence: Defining a Path Forward. Cell 2019, 179, 813-827. [CrossRef]

107. Hernandez-Segura, A.; Nehme, J.; Demaria, M. Hallmarks of Cellular Senescence. Trends Cell Biol. 2018, 28, 436-453. [CrossRef]

108. Martínez-Zamudio, R.I.; Robinson, L.; Roux, P.F.; Bischof, O. SnapShot: Cellular Senescence Pathways. Cell 2017, $170,816-816 . e 1$. [CrossRef]

109. Baker, D.J.; Wijshake, T.; Tchkonia, T.; Lebrasseur, N.K.; Childs, B.G.; Van De Sluis, B.; Kirkland, J.L.; Van Deursen, J.M. Clearance of p16Ink4a-positive senescent cells delays ageing-associated disorders. Nature 2011, 479, 232-236. [CrossRef]

110. Burd, C.E.; Sorrentino, J.A.; Clark, K.S.; Darr, D.B.; Krishnamurthy, J.; Deal, A.M.; Bardeesy, N.; Castrillon, D.H.; Beach, D.H.; Sharpless, N.E. Monitoring tumorigenesis and senescence in vivo with a p16INK4a-luciferase model. Cell 2013, 152, 340-351. [CrossRef]

111. Zhu, B.; Gong, Y.; Yan, G.; Wang, D.; Wang, Q.; Qiao, Y.; Hou, J.; Liu, B.; Tang, C. Atorvastatin treatment modulates p16 promoter methylation to regulate p16 expression. FEBS J. 2017, 284, 1868-1881. [CrossRef] [PubMed]

112. Li, J.; Poi, M.J.; Tsai, M.D. Regulatory mechanisms of tumor suppressor P16INK4A and their relevance to cancer. Biochemistry 2011, 50, 5566-5582. [CrossRef] [PubMed]

113. Koo, B.H.; Kim, Y.; Je Cho, Y.; Kim, D.S. Distinct roles of transforming growth factor- $\beta$ signaling and transforming growth factor- $\beta$ receptor inhibitor SB431542 in the regulation of p21 expression. Eur. J. Pharmacol. 2015, 764, 413-423. [CrossRef] [PubMed]

114. Jung, Y.S.; Qian, Y.; Chen, X. Examination of the expanding pathways for the regulation of p21 expression and activity. Cell. Signal. 2010, 22, 1003-1012. [CrossRef]

115. Al-Khalaf, H.H.; Aboussekhra, A. p16INK4A positively regulates p21(WAF1) expression by suppressing AUF1-dependent mRNA decay. PLoS ONE 2013, 8, e70133. [CrossRef]

116. Zou, L. Single- and double-stranded DNA: Building a trigger of ATR-mediated DNA damage response. Genes Dev. 2007, 21, 879-885. [CrossRef]

117. Shiloh, Y. The ATM-mediated DNA-damage response: Taking shape. Trends Biochem. Sci. 2006, 31, 402-410. [CrossRef]

118. Ayrapetov, M.K.; Gursoy-Yuzugullu, O.; Xu, C.; Xu, Y.; Price, B.D. DNA double-strand breaks promote methylation of histone H3 on lysine 9 and transient formation of repressive chromatin. Proc. Natl. Acad. Sci. USA 2014, 111, 9169-9174. [CrossRef]

119. Biran, A.; Zada, L.; Abou Karam, P.; Vadai, E.; Roitman, L.; Ovadya, Y.; Porat, Z.; Krizhanovsky, V. Quantitative identification of senescent cells in aging and disease. Aging Cell 2017, 16, 661-671. [CrossRef]

120. Summer, R.; Shaghaghi, H.; Schriner, D.L.; Roque, W.; Sales, D.; Cuevas-Mora, K.; Desai, V.; Bhushan, A.; Ramirez, M.I.; Romero, F. Activation of the mTORC1/PGC-1 axis promotes mitochondrial biogenesis and induces cellular senescence in the lung epithelium. Am. J. Physiol. Lung Cell. Mol. Physiol. 2019, 316, L1049-L1060. [CrossRef]

121. Sun, Y.; Coppé, J.P.; Lam, E.W.F. Cellular Senescence: The Sought or the Unwanted? Trends Mol. Med. 2018, 24, 871-885. [CrossRef]

122. Lopes-Paciencia, S.; Saint-Germain, E.; Rowell, M.C.; Ruiz, A.F.; Kalegari, P.; Ferbeyre, G. The senescence-associated secretory phenotype and its regulation. Cytokine 2019, 117, 15-22. [CrossRef]

123. Tanaka, Y.; Takahashi, A. Senescence-associated extracellular vesicle release plays a role in senescence-associated secretory phenotype (SASP) in age-associated diseases. J. Biochem. 2021, 169, 147-153. [CrossRef]

124. Coppé, J.P.; Patil, C.K.; Rodier, F.; Sun, Y.; Muñoz, D.P.; Goldstein, J.; Nelson, P.S.; Desprez, P.Y.; Campisi, J. Senescence-associated secretory phenotypes reveal cell-nonautonomous functions of oncogenic RAS and the p53 tumor suppressor. PLoS Biol. 2008, 6, 2853-2868. [CrossRef]

125. Maciel-Barón, L.A.; Morales-Rosales, S.L.; Aquino-Cruz, A.A.; Triana-Martínez, F.; Galván-Arzate, S.; Luna-López, A.; GonzálezPuertos, V.Y.; López-Díazguerrero, N.E.; Torres, C.; Königsberg, M. Senescence associated secretory phenotype profile from primary lung mice fibroblasts depends on the senescence induction stimuli. Age 2016, 38, 26. [CrossRef]

126. Kumari, R.; Jat, P. Mechanisms of Cellular Senescence: Cell Cycle Arrest and Senescence Associated Secretory Phenotype. Front. Cell Dev. Biol. 2021, 9, 645593. [CrossRef]

127. Kale, A.; Sharma, A.; Stolzing, A.; Stolzing, A.; Desprez, P.Y.; Desprez, P.Y.; Campisi, J.; Campisi, J. Role of immune cells in the removal of deleterious senescent cells. Immun. Ageing 2020, 17, 16. [CrossRef]

128. Childs, B.G.; Gluscevic, M.; Baker, D.J.; Laberge, R.M.; Marquess, D.; Dananberg, J.; Van Deursen, J.M. Senescent cells: An emerging target for diseases of ageing. Nat. Rev. Drug Discov. 2017, 16, 718-735. [CrossRef] 
129. Coppé, J.P.; Desprez, P.Y.; Krtolica, A.; Campisi, J. The senescence-associated secretory phenotype: The dark side of tumor suppression. Annu. Rev. Pathol. 2010, 5, 99-118. [CrossRef]

130. Ortiz-Montero, P.; Londoño-Vallejo, A.; Vernot, J.P. Senescence-associated IL-6 and IL-8 cytokines induce a self- and crossreinforced senescence/inflammatory milieu strengthening tumorigenic capabilities in the MCF-7 breast cancer cell line. Cell Commun. Signal. 2017, 15, 17. [CrossRef]

131. Gasek, N.S.; Kuchel, G.A.; Kirkland, J.L.; Xu, M. Strategies for targeting senescent cells in human disease. Nat. Aging 2021, 1, 870-879. [CrossRef]

132. Rübe, C.E.; Bäumert, C.; Schuler, N.; Isermann, A.; Schmal, Z.; Glanemann, M.; Mann, C.; Scherthan, H. Human skin aging is associated with increased expression of the histone variant H2A.J in the epidermis. NPJ Aging Mech. Dis. 2021, 7, 7. [CrossRef]

133. Campisi, J.; D’Adda Di Fagagna, F. Cellular senescence: When bad things happen to good cells. Nat. Rev. Mol. Cell Biol. 2007, 8 , 729-740. [CrossRef]

134. Freund, A.; Laberge, R.M.; Demaria, M.; Campisi, J. Lamin B1 loss is a senescence-associated biomarker. Mol. Biol. Cell 2012, 23, 2066-2075. [CrossRef]

135. Funayama, R.; Ishikawa, F. Cellular senescence and chromatin structure. Chromosoma 2007, 116, 431-440. [CrossRef]

136. Childs, B.G.; Baker, D.J.; Kirkland, J.L.; Campisi, J.; Deursen, J.M. Senescence and apoptosis: Dueling or complementary cell fates? EMBO Rep. 2014, 15, 1139-1153. [CrossRef]

137. Debacq-Chainiaux, F.; Erusalimsky, J.D.; Campisi, J.; Toussaint, O. Protocols to detect senescence-associated beta-galactosidase (SA-betagal) activity, a biomarker of senescent cells in culture and in vivo. Nat. Protoc. 2009, 4, 1798-1806. [CrossRef]

138. Gallage, S.; Gil, J. Mitochondrial Dysfunction Meets Senescence. Trends Biochem. Sci. 2016, 41, 207-209. [CrossRef]

139. Guerra, C.; Schuhmacher, A.J.; Cañamero, M.; Grippo, P.J.; Verdaguer, L.; Pérez-Gallego, L.; Dubus, P.; Sandgren, E.P.; Barbacid, M. Chronic pancreatitis is essential for induction of pancreatic ductal adenocarcinoma by K-Ras oncogenes in adult mice. Cancer Cell 2007, 11, 291-302. [CrossRef]

140. Caldwell, M.E.; Denicola, G.M.; Martins, C.P.; Jacobetz, M.A.; Maitra, A.; Hruban, R.H.; Tuveson, D.A. Cellular features of senescence during the evolution of human and murine ductal pancreatic cancer. Oncogene 2012, 31, 1599-1608. [CrossRef]

141. Frey, N.; Venturelli, S.; Zender, L.; Bitzer, M. Cellular senescence in gastrointestinal diseases: From pathogenesis to therapeutics. Nat. Rev. Gastroenterol. Hepatol. 2018, 15, 81-95. [CrossRef] [PubMed]

142. Bardeesy, N.; Aguirre, A.J.; Chu, G.C.; Cheng, K.H.; Lopez, L.V.; Hezel, A.F.; Feng, B.; Brennan, C.; Weissleder, R.; Mahmood, U.; et al. Both p16Ink4a and the p19(Arf)-p53 pathway constrain progression of pancreatic adenocarcinoma in the mouse. Proc. Natl. Acad. Sci. USA 2006, 103, 5947-5952. [CrossRef] [PubMed]

143. Hansel, D.E.; Kern, S.E.; Hruban, R.H. Molecular pathogenesis of pancreatic cancer. Annu. Rev. Genomics Hum. Genet. 2003, 4, 237-256. [CrossRef] [PubMed]

144. Ag Moir, J.; A. White, S.; Mann, J. Arrested development and the great escape-the role of cellular senescence in pancreatic cancer. Int. J. Biochem. Cell Biol. 2014, 57, 142-148. [CrossRef] [PubMed]

145. Makohon-Moore, A.; Iacobuzio-Donahue, C.A. Pancreatic cancer biology and genetics from an evolutionary perspective. Nat. Rev. Cancer 2016, 16, 553-565. [CrossRef]

146. Singh, S.K.; Ellenrieder, V. Senescence in pancreatic carcinogenesis: From signalling to chromatin remodelling and epigenetics. Gut 2013, 62, 1364-1372. [CrossRef]

147. Beauséjour, C.M.; Krtolica, A.; Galimi, F.; Narita, M.; Lowe, S.W.; Yaswen, P.; Campisi, J. Reversal of human cellular senescence: Roles of the p53 and p16 pathways. EMBO J. 2003, 22, 4212-4222. [CrossRef]

148. Peeper, D.S.; Dannenberg, J.H.; Douma, S.; Te Riele, H.; Bernards, R. Escape from premature senescence is not sufficient for oncogenic transformation by Ras. Nat. Cell Biol. 2001, 3, 198-203. [CrossRef]

149. Lowenfels, A.B.; Maisonneuve, P. Epidemiology and risk factors for pancreatic cancer. Best Pract. Res. Clin. Gastroenterol. 2006, 20, 197-209. [CrossRef]

150. Malumbres, M.; Barbacid, M. Cell cycle, CDKs and cancer: A changing paradigm. Nat. Rev. Cancer 2009, 9, 153-166. [CrossRef]

151. Kennedy, A.L.; Morton, J.P.; Manoharan, I.; Nelson, D.M.; Jamieson, N.B.; Pawlikowski, J.S.; McBryan, T.; Doyle, B.; McKay, C.; Oien, K.A.; et al. Activation of the PIK3CA/AKT pathway suppresses senescence induced by an activated RAS oncogene to promote tumorigenesis. Mol. Cell 2011, 42, 36-49. [CrossRef]

152. Sun, P.; Yoshizuka, N.; New, L.; Moser, B.A.; Li, Y.; Liao, R.; Xie, C.; Chen, J.; Deng, Q.; Yamout, M.; et al. PRAK is essential for ras-induced senescence and tumor suppression. Cell 2007, 128, 295-308. [CrossRef]

153. Wang, J.; Kobayashi, T.; Floc'h, N.; Kinkade, C.W.; Aytes, A.; Dankort, D.; Lefebvre, C.; Mitrofanova, A.; Cardiff, R.D.; McMahon, M.; et al. B-Raf activation cooperates with PTEN loss to drive c-Myc expression in advanced prostate cancer. Cancer Res. 2012, 72, 4765-4776. [CrossRef]

154. Tront, J.S.; Hoffman, B.; Liebermann, D.A. Gadd45a suppresses Ras-driven mammary tumorigenesis by activation of c-Jun $\mathrm{NH} 2$-terminal kinase and 338 stress signaling resulting in apoptosis and senescence. Cancer Res. 2006, 66, 8448-8454. [CrossRef]

155. Fritsche, P.; Seidler, B.; Schüler, S.; Schnieke, A.; Göttlicher, M.; Schmid, R.M.; Saur, D.; Schneider, G. HDAC2 mediates therapeutic resistance of pancreatic cancer cells via the BH3-only protein NOXA. Gut 2009, 58, 1399-1409. [CrossRef]

156. Ling, J.; Kang, Y.; Zhao, R.; Xia, Q.; Lee, D.F.; Chang, Z.; Li, J.; Peng, B.; Fleming, J.B.; Wang, H.; et al. KrasG12D-induced IKK $2 / \beta / N F-\kappa B$ activation by IL- $1 \alpha$ and $p 62$ feedforward loops is required for development of pancreatic ductal adenocarcinoma. Cancer Cell 2012, 21, 105-120. [CrossRef] 
157. Jochems, F.; Thijssen, B.; De Conti, G.; Jansen, R.; Pogacar, Z.; Groot, K.; Wang, L.; Schepers, A.; Wang, C.; Jin, H.; et al. The Cancer SENESCopedia: A delineation of cancer cell senescence. Cell Rep. 2021, 36, 109441. [CrossRef]

158. Holmer, R.; Goumas, F.A.; Waetzig, G.H.; Rose-John, S.; Kalthoff, H. Interleukin-6: A villain in the drama of pancreatic cancer development and progression. Hepatobiliary Pancreat. Dis. Int 2014, 13, 371-380. [CrossRef]

159. Slapak, E.J.; Duitman, J.; Tekin, C.; Bijlsma, M.F.; Spek, C.A. Matrix Metalloproteases in Pancreatic Ductal Adenocarcinoma: Key Drivers of Disease Progression? Biology 2020, 9, 80. [CrossRef]

160. Yako, Y.Y.; Kruger, D.; Smith, M.; Brand, M. Cytokines as Biomarkers of Pancreatic Ductal Adenocarcinoma: A Systematic Review. PLoS ONE 2016, 11, e0154016. [CrossRef]

161. Lawrence, T. The nuclear factor NF-kappaB pathway in inflammation. Cold Spring Harb. Perspect. Biol. 2009, 1, a001651. [CrossRef]

162. Feng, L.; Qi, Q.; Wang, P.; Chen, H.; Chen, Z.; Meng, Z.; Liu, L. Serum levels of IL-6, IL-8, and IL-10 are indicators of prognosis in pancreatic cancer. J. Int. Med. Res. 2018, 46, 5228-5236. [CrossRef]

163. Chen, I.M.; Johansen, A.Z.; Dehlendorff, C.; Jensen, B.V.; Bojesen, S.E.; Pfeiffer, P.; Bjerregaard, J.K.; Nielsen, S.E.; Andersen, F.; Holländer, N.H.; et al. Prognostic Value of Combined Detection of Serum IL6, YKL-40, and C-reactive Protein in Patients with Unresectable Pancreatic Cancer. Cancer Epidemiol. Biomark. Prev. 2020, 29, 176-184. [CrossRef]

164. Lesina, M.; Wörmann, S.M.; Neuhöfer, P.; Song, L.; Algül, H. Interleukin-6 in inflammatory and malignant diseases of the pancreas. Semin. Immunol. 2014, 26, 80-87. [CrossRef]

165. Fitzner, B.; Müller, S.; Walther, M.; Fischer, M.; Engelmann, R.; Müller-Hilke, B.; Pützer, B.M.; Kreutzer, M.; Nizze, H.; Jaster, R. Senescence determines the fate of activated rat pancreatic stellate cells. J. Cell. Mol. Med. 2012, 16, 2620-2630. [CrossRef]

166. Shao, C.; Tu, C.; Cheng, X.; Xu, Z.; Wang, X.; Shen, J.; Chai, K.; Chen, W. Inflammatory and Senescent Phenotype of Pancreatic Stellate Cells Induced by Sqstm1 Downregulation Facilitates Pancreatic Cancer Progression. Int. J. Biol. Sci. 2019, 15, 1020-1029. [CrossRef]

167. Straub, J.M.; New, J.; Hamilton, C.D.; Lominska, C.; Shnayder, Y.; Thomas, S.M. Radiation-induced fibrosis: Mechanisms and implications for therapy. J. Cancer Res. Clin. Oncol. 2015, 141, 1985-1994. [CrossRef]

168. Ragunathan, K.; Upfold, N.L.E.; Oksenych, V. Interaction between Fibroblasts and Immune Cells Following DNA Damage Induced by Ionizing Radiation. Int. J. Mol. Sci. 2020, 21, 8635. [CrossRef] [PubMed]

169. Krisnawan, V.E.; Stanley, J.A.; Schwarz, J.K.; Denardo, D.G. Tumor Microenvironment as a Regulator of Radiation Therapy: New Insights into Stromal-Mediated Radioresistance. Cancers 2020, 12, 2916. [CrossRef] [PubMed]

170. Wang, T.; Notta, F.; Navab, R.; Joseph, J.; Ibrahimov, E.; Xu, J.; Zhu, C.Q.; Borgida, A.; Gallinger, S.; Tsao, M.S. Senescent Carcinoma-Associated Fibroblasts Upregulate IL8 to Enhance Prometastatic Phenotypes. Mol. Cancer Res. 2017, 15, 3-14. [CrossRef] [PubMed]

171. Ansems, M.; Span, P.N. The tumor microenvironment and radiotherapy response; a central role for cancer-associated fibroblasts. Clin. Transl. Radiat. Oncol. 2020, 22, 90-97. [CrossRef]

172. Levi, N.; Papismadov, N.; Solomonov, I.; Sagi, I.; Krizhanovsky, V. The ECM path of senescence in aging: Components and modifiers. FEBS J. 2020, 287, 2636-2646. [CrossRef]

173. Blokland, K.E.C.; Pouwels, S.D.; Schuliga, M.; Knight, D.A.; Burgess, J.K. Regulation of cellular senescence by extracellular matrix during chronic fibrotic diseases. Clin. Sci. 2020, 134, 2681-2706. [CrossRef]

174. Hwang, H.J.; Lee, Y.R.; Kang, D.; Lee, H.C.; Seo, H.R.; Ryu, J.K.; Kim, Y.N.; Ko, Y.G.; Park, H.J.; Lee, J.S. Endothelial cells under therapy-induced senescence secrete CXCL11, which increases aggressiveness of breast cancer cells. Cancer Lett. 2020, 490, 100-110. [CrossRef]

175. Wang, D.; Xiao, F.; Feng, Z.; Li, M.; Kong, L.; Huang, L.; Wei, Y.; Li, H.; Liu, F.; Zhang, H.; et al. Sunitinib facilitates metastatic breast cancer spreading by inducing endothelial cell senescence. Breast Cancer Res. 2020, 22, 103. [CrossRef]

176. Ruscetti, M.; Morris, J.P.; Mezzadra, R.; Russell, J.; Leibold, J.; Romesser, P.B.; Simon, J.; Kulick, A.; Ho, Y.jui; Fennell, M.; et al. Senescence-Induced Vascular Remodeling Creates Therapeutic Vulnerabilities in Pancreas Cancer. Cell 2021, 184, 4838-4839. [CrossRef]

177. Lian, J.; Yue, Y.; Yu, W.; Zhang, Y. Immunosenescence: A key player in cancer development. J. Hematol. Oncol. $2020,13,151$. [CrossRef]

178. Prata, L.G.P.L.; Ovsyannikova, I.G.; Tchkonia, T.; Kirkland, J.L. Senescent cell clearance by the immune system: Emerging therapeutic opportunities. Semin. Immunol. 2018, 40, 101275. [CrossRef]

179. Song, P.; An, J.; Zou, M.H. Immune Clearance of Senescent Cells to Combat Ageing and Chronic Diseases. Cells 2020, 9, 671. [CrossRef]

180. Kang, T.W.; Yevsa, T.; Woller, N.; Hoenicke, L.; Wuestefeld, T.; Dauch, D.; Hohmeyer, A.; Gereke, M.; Rudalska, R.; Potapova, A.; et al. Senescence surveillance of pre-malignant hepatocytes limits liver cancer development. Nature 2011, 479, 547-551. [CrossRef]

181. Ye, J.; Huang, X.; Hsueh, E.C.; Zhang, Q.; Ma, C.; Zhang, Y.; Varvares, M.A.; Hoft, D.F.; Peng, G. Human regulatory T cells induce T-lymphocyte senescence. Blood 2012, 120, 2021-2031. [CrossRef]

182. Ye, J.; Ma, C.; Hsueh, E.C.; Eickhoff, C.S.; Zhang, Y.; Varvares, M.A.; Hoft, D.F.; Peng, G. Tumor-derived $\gamma \delta$ regulatory T cells suppress innate and adaptive immunity through the induction of immunosenescence. J. Immunol. 2013, 190, 2403-2414. [CrossRef] 
183. Ruhland, M.K.; Loza, A.J.; Capietto, A.H.; Luo, X.; Knolhoff, B.L.; Flanagan, K.C.; Belt, B.A.; Alspach, E.; Leahy, K.; Luo, J.; et al. Stromal senescence establishes an immunosuppressive microenvironment that drives tumorigenesis. Nat. Commun. 2016, 7, 11762. [CrossRef]

184. Etxebeste-Mitxeltorena, M.; del Rincón-Loza, I.; Martín-Antonio, B. Tumor Secretome to Adoptive Cellular Immunotherapy: Reduce Me Before I Make You My Partner. Front. Immunol. 2021, 12, 3201. [CrossRef]

185. Elkabets, M.; Ribeiro, V.S.G.; Dinarello, C.A.; Ostrand-Rosenberg, S.; Di Santo, J.P.; Apte, R.N.; Vosshenrich, C.A.J. IL-1 $\beta$ regulates a novel myeloid-derived suppressor cell subset that impairs NK cell development and function. Eur. J. Immunol. 2010, 40, 3347-3357. [CrossRef]

186. Wu, J.; Gao, F.X.; Wang, C.; Qin, M.; Han, F.; Xu, T.; Hu, Z.; Long, Y.; He, X.M.; Deng, X.; et al. IL-6 and IL-8 secreted by tumour cells impair the function of NK cells via the STAT3 pathway in oesophageal squamous cell carcinoma. J. Exp. Clin. Cancer Res. 2019, 38, 321. [CrossRef]

187. Behmoaras, J.; Gil, J. Similarities and interplay between senescent cells and macrophages. J. Cell Biol. 2021, 220, e202010162. [CrossRef]

188. Ogata, Y.; Yamada, T.; Hasegawa, S.; Sanada, A.; Iwata, Y.; Arima, M.; Nakata, S.; Sugiura, K.; Akamatsu, H. SASP-induced macrophage dysfunction may contribute to accelerated senescent fibroblast accumulation in the dermis. Exp. Dermatol. 2021, 30, 84-91. [CrossRef]

189. Lesina, M.; Wörmann, S.M.; Morton, J.; Diakopoulos, K.N.; Korneeva, O.; Wimmer, M.; Einwächter, H.; Sperveslage, J.; Demir, I.E.; Kehl, T.; et al. RelA regulates CXCL1/CXCR2-dependent oncogene-induced senescence in murine Kras-driven pancreatic carcinogenesis. J. Clin. Investig. 2016, 126, 2919-2932. [CrossRef]

190. Bailey, P.; Chang, D.K.; Nones, K.; Johns, A.L.; Patch, A.M.; Gingras, M.C.; Miller, D.K.; Christ, A.N.; Bruxner, T.J.C.; Quinn, M.C.; et al. Genomic analyses identify molecular subtypes of pancreatic cancer. Nature 2016, 531, 47-52. [CrossRef]

191. Demoor-Goldschmidt, C.; De Vathaire, F. Review of risk factors of secondary cancers among cancer survivors. Br. J. Radiol. 2019, 92, 1093. [CrossRef] [PubMed]

192. Ducreux, M.; Sa Cuhna, A.; Caramella, C.; Hollebecque, A.; Burtin, P.; Goéré, D.; Seufferlein, T.; Haustermans, K.; Van Laethem, J.L.; Brousse, P. Cancer of the pancreas: ESMO Clinical Practice Guidelines for diagnosis, treatment and follow-up. ESMO Updat. Clin. Pract. Guidel. 2015, 26, v56-v68. [CrossRef] [PubMed]

193. Campisi, J.; Kapahi, P.; Lithgow, G.J.; Melov, S.; Newman, J.C.; Verdin, E. From discoveries in ageing research to therapeutics for healthy ageing. Nature 2019, 571, 183-192. [CrossRef] [PubMed] 